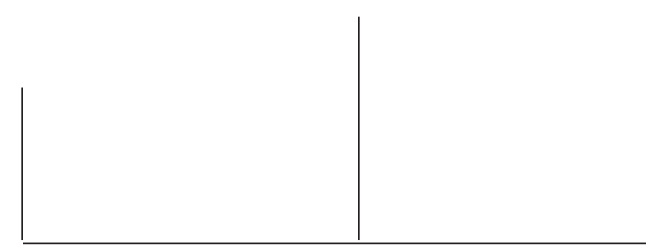

Rev. Latinoam. Psicopat. Fund., III, 2, 98-128

\title{
O desejo na Grécia Helenística
}

\author{
Zeferino Rocha
}

O presente trabalho é a terceira e última parte de uma pesquisa sobre "O desejo na Grécia Antiga". Na primeira parte, reunimos as manifestações do desejo nos poemas épicos, líricos e trágicos, bem como nas máximas dos sete sábios e na doutrina dos filósofos pré-socráticos da Grécia Arcaica. Na segunda, apresentamos o essencial da sistematização teórica que, na Grécia Clássica, Sócrates, Platão e Aristóteles deram a essas primeiras manifestações do desejo. Nesta última parte, depois de lembrar a origem e as características da cultura helenística, vamos ver o que os epicuristas e os estóicos, no contexto de suas respectivas filosofias, disseram sobre o desejo no Jardim de Epicuro e no Pórtico Antigo de Zenão e Crísipo.

Palavras-chave: Cultura helenística, arte de viver, prazer, virtude, felicidade 


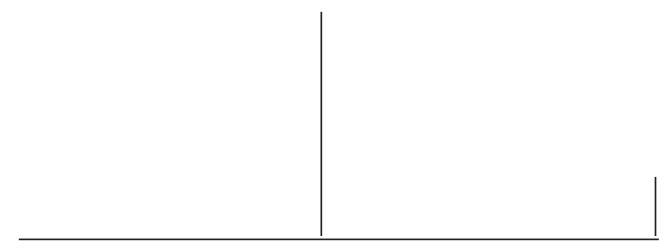

Introdução

\section{A cultura helenística}

A conquista do Oriente feita por Alexandre Magno e a expansão da cultura helênica, através de quase todo o mundo até então habitado, produziram um fenômeno cultural novo de proporções gigantescas, que se costuma designar com o nome de Helenismo. Este fenômeno deu início a uma nova época na história da Grécia Antiga, marcada por um novo "espírito do tempo" (um novo Zeitgeist, diriam os alemães) inteiramente diferente daquele que dominou a Grécia Clássica.

Na civilização helenística, o que mais traumatizou a mentalidade da Hélade foi certamente o progressivo desaparecimento do papel e da importante função

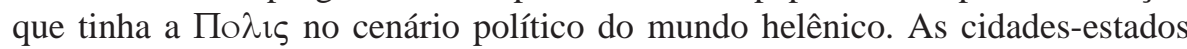
independentes - que, desde o século de Péricles, proporcionaram, pela primeira vez, na história da Humanidade, a experiência ímpar da democracia - foram submetidas ao ambicioso projeto de uma monarquia universal, que começou a ser realizado por Felipe, rei da Macedônia, e se fortaleceu com as conquistas do seu filho Alexandre Magno.

Para governar tão imenso Império, Alexandre teve de ser revestido de poderes divinos, os quais, no entanto, não impediram que ele morresse ainda jovem. Depois de sua morte, os reinos helenísticos foram, pouco a pouco, perdendo sua força e coesão políticas e, no ano 146 a.C., a Grécia foi reduzida a uma província romana, e Roma, que no dizer de Léon Robin, foi a "herdeira da ambição de Alexandre", tornou-se a capital do Mundo. ${ }^{1}$ Todavia, embora vencida, a cultura helênica não perdeu sua soberania cultural e foi ela que vitalizou a cultura romana, como tão bem o disse Horácio numa frase quem a história da literatura latina imortalizou:

Graecia capta ferum victorem cepit et artes intulit agresti Latio,

vale dizer, "a Grécia vencida apoderou-se do vencedor selvagem e trouxe as artes para o agreste Lácio”. ${ }^{2}$

1. Léon Robin, La pensée grecque et les origines de l'esprit scientifique. Paris: Albin Michel, 1948, p. 375.

2. Horatius, Epistula II, 1, v. 156. 


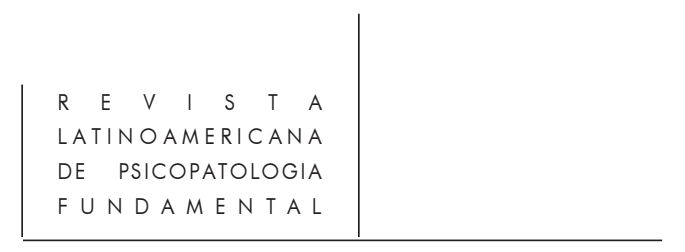

Um novo ethos

Na Grécia Clássica, o homem era, antes e acima de tudo, um cidadão, isto é, alguém seriamente engajado na vida da Пo $\lambda \iota \varsigma$, pois, segundo a definição de Aristóteles, o homem é essencialmente um animal político ( $\left.\omega_{\omega \circ} \pi_{0} \lambda \imath \tau \imath \kappa \circ v\right)$. A cultura cosmopolita da época helenística modificou completamente o modo de vida tradicional do povo grego. As virtudes cívicas e políticas praticamente perderam sua razão de ser, pois a res publica deixou de ser regida pelas "assembléias das cidades", e passou a ser trabalho dos administradores do Império.

Perdendo seu status de cidadão, o homem tornou-se um súdito do imperador e a passagem da condição de cidadão para a de súdito modificou completamente o estilo de sua vida. Não encontrando mais, na Пo $\lambda \iota \varsigma$, a proteção que tivera antes, o homem da Grécia helenística foi, como observa Giovanni Reale, “... coagido pela força dos acontecimentos a fechar-se em si mesmo, a buscar no seu íntimo novas energias, novos conteúdos morais e novas metas pelas quais viver. Assim, o homem descobriu-se como indivíduo". ${ }^{3}$ Não contando mais com a tutela do Estado, o indivíduo tinha de tomar, nas suas mãos, as rédeas de seu próprio destino.

\section{Universalismo e individualismo}

A civilização helenística tinha duas características essencialmente diferentes e contrastantes: de um lado, ela era uma civilização universal e cosmopolita e, do outro, uma civilização na qual predominava o individualismo.

O universalismo cosmopolita teve o merecimento de fazer ruir os preconceitos e as barreiras que, na Grécia Arcaica e na Grécia Clássica, separavam os helenos dos demais povos, os quais eram chamados de bárbaros, simplesmente porque se encontravam além das fronteiras da Hélade. Foram também mitigados os preconceitos contra os escravos e as mulheres que não possuíam direitos políticos de cidadania, nem tinham acesso à educação. Epicuro abriu as portas de seu Jardim às mulheres e os estóicos disseram, com muita sabedoria, que a verdadeira escravidão era a ignorância.

Neste sentido, a civilização helenística teve uma influência marcante na fisionomia intelectual do Ocidente. ${ }^{4}$ A civilização da paideia como a chamou Henri-

3. Giovanni Reale. História da filosofia Antiga. Os sistemas da era helenística. Trad.Marcelo Perine. São Paulo: Loyola, vol. III, p.7.

4. Sobre a civilização helenística ver o livro de P. Pétit. La civilization hellénistique. Paris: PUF, 1962; e o livro de Léon Robin, La pensée hellénique. Des origines à Épicure. Paris: PUF, 1967. 


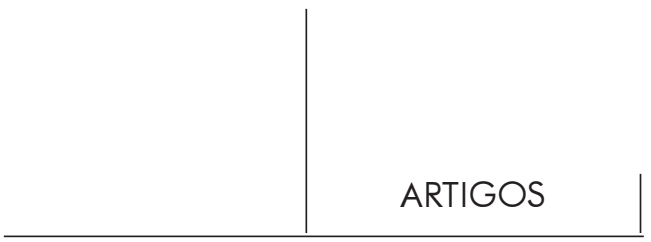

Irinée Marrou, tornou-se, na interpretação de Henrique de Lima Vaz , "um tipo ideal de humanidade e o berço da idéia de humanismo". 5

A filosofia, uma arte de viver

Neste novo clima cultural, a filosofia de Platão e a política de Aristóteles foram desacreditadas no que tinham de mais importante, ou seja, na sua dimensão metafísica, e por causa do total desmoronamento dos valores que marcaram a era clássica, os novos filósofos tiveram de enfrentar o desafio de apresentar aos homens de seu tempo uma nova finalidade para o filosofar. Uma filosofia que se transformasse numa arte de viver bem.

Desfeitos os horizontes da transcendência, os homens passaram a procurar a felicidade, ou seja, o fim último da vida, naquilo que se podia encontrar dentro do próprio mundo no qual viviam. E todos os grandes sistemas que marcaram o pensamento filosófico, neste período, foram unânimes em afirmar que o segredo da felicidade estava na "paz do espírito" ( $\alpha \tau \alpha \rho \alpha \chi 1 \alpha)$, que, em geral, só se conseguia ao preço de uma dolorosa renúncia às paixões e de uma severa ascese dos desejos.

Nestas reflexões sobre a cultura helenística, restringir-me-ei ao que, no Jardim de Epicuro e no Pórtico antigo de Zenão e Crísipo, disseram os epicuristas e os estóicos, no contexto de suas respectivas teorias filosóficas, sobre o desejo e os destinos do desejo.

\section{No Jardim de Epicuro}

Um certo Diógenes, discípulo de Epicuro, gravou, nas muralhas de Enoanda, cidade situada na Lícia (Ásia Menor), no século II d.C., várias sentenças do mestre, entre as quais se podia ler a seguinte frase: "Hoje, por causa das falsas crenças a respeito do mundo, a maioria dos homens está doente". ${ }^{6}$

Foi precisamente para oferecer uma possibilidade de cura a todos esses homens doentes de seu tempo (e não apenas a uma pequena elite como se fazia na Academia

5. Henri-Irinée Marrou. Histoire d l'éducation dans l'Antiquité. Paris: Seuil, 1965, pp. 151-160. Henrique C. de Lima Vaz. Escritos de filosofia IV. Introdução à ética filosófica 1. São Paulo: Loyola, 1999, p. 129.

6. Giovanni Reale. História da filosofia antiga. Escolas da era imperial. Trad. Marcelo Perine e Henrique C. de Lima Vaz. São Paulo: Loyola, 1994, vol. IV, p. 55. Esta inscrição das muralhas de Enoanda encontra-se, hoje, entre os poucos fragmentos da doutrina de Epicuro, que chegaram até os nossos dias. 


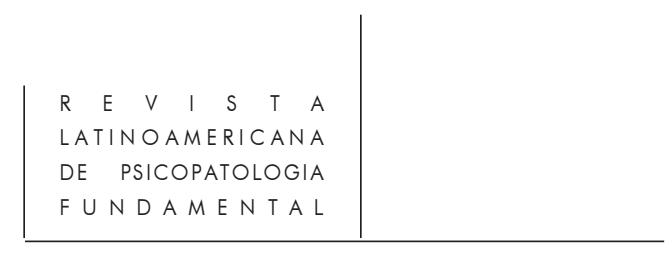

e no Liceu) que Epicuro criou o famoso Jardim. Na realidade, o Jardim era muito mais um horto $(\kappa \eta \pi \circ \varsigma)$, do que propriamente um parque de delícias $(\pi \alpha \rho \alpha \delta \varepsilon 1 \sigma \circ \varsigma)$, ou, ainda, um Éden, como insinuaram alguns inimigos de Epicuro - entre eles, o próprio Cícero - ao afirmarem que, no Jardim, os discípulos de Epicuro praticavam todas as formas de prazer libidinoso. ${ }^{7}$

É verdade que, segundo o testemunho de Sêneca, havia na entrada do Jardim uma inscrição com as seguintes palavras: "Hospes, hic bene manebis, hic summum bonum, voluptas est" (Oh hóspede, aqui permanecerás bem, aqui está o supremo bem, o prazer). ${ }^{8}$ Mas, é preciso esclarecer, como tentaremos fazê-lo mais adiante, o que Epicuro entendia por prazer.

Situado no silêncio dos campos, o Jardim de Epicuro era um refúgio contra o barulho da cidade. Se a felicidade, em última análise, só se conseguia com a paz da alma, era muito compreensível a preocupação de Epicuro em querer fugir do barulho e da agitação das grandes cidades e ir viver na paz dos campos. Apesar do espírito da época, uma característica da escola epicurista era uma quase aversão ao domínio público e às multidões.

\section{A amizade}

No Jardim, os discípulos viviam unidos, entre si, pelos laços da amizade $(\varphi \imath \lambda \imath \alpha) .{ }^{9}$ Assim unidos, eles se dedicavam ao exercício de "filosofar em comum"

7. Veja-se a este respeito o artigo de José Américo Motta Pessanha. As delícias do Jardim. In Adauto Novaes (org.). Ética. São Paulo: Companhia das Letras, 1993, p. 62. Como veremos melhor mais adiante, nada mais contrário à doutrina de Epicuro do que imaginar seus discípulos como hedonistas que tudo sacrificavam aos prazeres imediatos dos sentidos: "comamos e bebamos porque amanhã morreremos".

8. Sêneca. Epistula XXI, 10. Usener, p. 81. Os fragmentos de Epicuro foram editados por Hermann Usener com o título Epicurea (Leipzig: Teubner, 1887) e reproduzido em 1966 (Stuttgart). Aos fragmentos reunidos por Usener foram acrescentadas as Sentenças Vaticanas, identificadas por K. Woltke, em 1888, e os fragmentos extraídos dos Papiros de Herculano provenientes da rica biblioteca do epicurista Filodemo (séc. I. a.C). Para mais informações, veja-se Henrique C. de Lima Vaz, op. cit., p. 133, nota 20. No presente trabalho, por não ter tido acesso ao livro de Hermann Usener, fiz as citações dos fragmentos a partir dos autores que foram minhas referências teóricas, particularmente Nemesius Gonzalez Caminero na sua Historia philosophiae antiquae. Altera Pars. Cyclus hellenisticus (s.III-I a.C.). Romae, apud Aedes Universitatis Gregorianae, 1960. Estas referências indiretas foram indicadas com a palavra "apud" e o nome do autor e a data do livro de onde tirei a referência.

9. Para Epicuro, a philia não tinha apenas um valor utilitário, mas era um bem em si. "De todas as coisas que a sabedoria oferece para a vida feliz, o maior bem é adquirido pela amizade." (Máxi- 


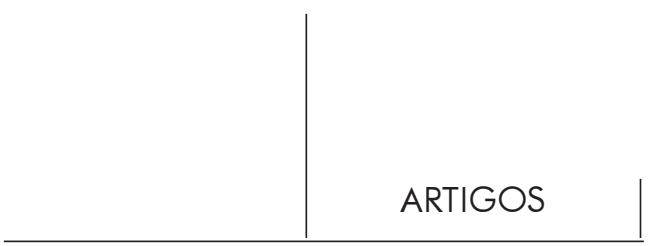

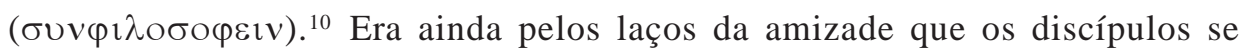
vinculavam ao mestre, a quem cultuavam com o respeito e a admiração devidos a um deus.

No magnífico poema que escreveu sobre a natureza das coisas (De Rerum Natura), Lucrécio refere-se a Epicuro como "a glória do povo grego" e o "descobridor da verdade". Sua doutrina era "a obra de um gênio divino". 11 Por causa do vínculo de união quase mística dos discípulos com seu mestre, a Escola de Epicuro revestia o aspecto de uma confraria, ou como disse Léon Robin, "de uma comunidade religiosa", embora em nada pudessem ser comparadas às seitas religiosas que existiram no passado, como, por exemplo, as seitas filosóficas dos pitagóricos. Este "culto do Mestre" foi também responsável pela ortodoxia rigorosa que caracterizou a doutrina do epicurismo, a qual em nada favoreceu seu desenvolvimento, nem antes nem depois da morte do mestre. ${ }^{12}$

Para Epicuro, a filosofia não podia ter outro objetivo senão o de "produzir uma

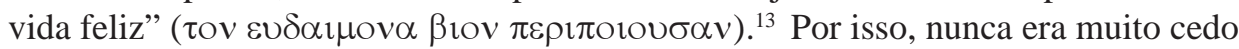
para começar a filosofar, nem muito tarde para deixar de filosofar, simplesmente porque nunca era cedo demais nem tarde demais para tratar da saúde da alma, nem para ser feliz.

\section{A doutrina de Epicuro}

Contrapondo-se às teses metafísicas de Platão e de Aristóteles que fundamentavam a felicidade $(\varepsilon \cup \delta \alpha 1 \mu \circ v 1 \alpha)$ ou no conhecimento intuitivo da idéia transcendental do Bem, ou na contemplação do Supremo inteligível e do supremo desejável (o que também era privilégio de poucos), Epicuro dizia que a felicidade estava ao alcance de todos e abria as portas do Jardim àqueles que, na Grécia Clássica, não gozavam do direito de cidadania, vale dizer, os estrangeiros e as mulheres (inclusive as prostitutas). Para ele, a felicidade consistia essencialmente

mas capitais, 27). Sobre a philia e o seu lugar no epicurismo, veja-se J. C. Fraise. Philia. La notion d'amitié dans la philosophie antique. Paris: Vrin, 1984, e o belo capítulo que lhe consagra A. J. Festugière no seu livro Épicure et ses Dieux. Paris: PUF, 1946, pp. 36-70.

10. Cicero. De Fin.. I, 20. Apud Léon Robin. La pensée grecque, loc. cit., p. 388.

11. O livro De Rerum Natura, de Lucrécio, é uma das fontes de que dispomos para conhecer a doutrina de Epicuro.

12. A este respeito seria interessante fazer um estudo comparativo entre o Jardim de Epicuro e o Pórtico de Zenão e de Crísipo. O Pórtico, pelo fato de ter tido mais de um diretor, teve um desenvolvimento doutrinário mais significativo do que aquele da Escola de Epicuro.

13. Usener, p. 219. Apud Nemesius Gonzalez Caminero, op. cit., p. 29. 


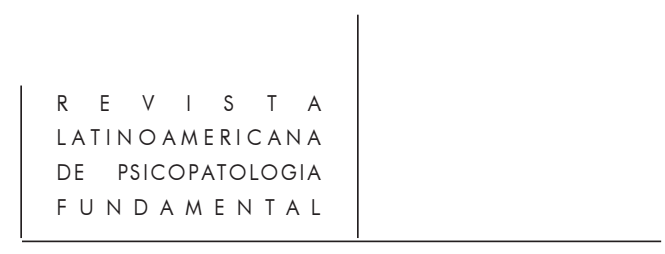

em duas coisas: libertar-se do medo e das preocupações inúteis e administrar os desejos para mantê-los nos limites impostos pela natureza.

Estas palavras resumem o essencial do novo ethos que Epicuro apresentou aos infelizes homens de seu tempo. Para fundamentá-lo filosoficamente, ele elabo-

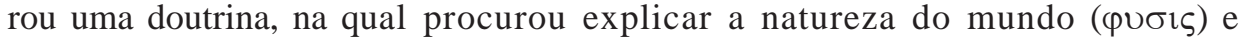

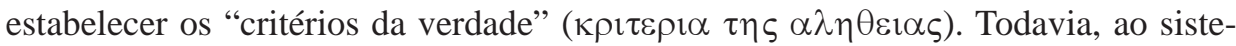
matizar esta doutrina filosófica, seu objetivo não foi construir uma filosofia do conhecimento (ou uma Canonica, como então se dizia), nem elaborar uma filosofia da natureza, mas colocar os fundamentos de sua doutrina ética. Os critérios da verdade e a visão do mundo ofereciam os subsídios necessários de que os homens necessitavam para, na busca da felicidade, não se iludirem com as crenças que os tornavam doentes.

\section{Os critérios da verdade}

Três são, para Epicuro, os critérios da verdade: a sensação ( $\alpha$ l $\sigma \theta \eta \sigma ı)$, a antecipação ou prenoção ( $\pi \rho \circ \lambda \eta \psi 1 \varsigma)$ e os sentimentos $(\pi \alpha \theta \eta)$. A sensação é o mais importante desses critérios, pois as coisas são como nós as sentimos. Conseqüentemente, a fonte de todos os erros não está em nossas sensações, mas em nossas crenças e em nossos juízos. Acreditar é imaginar o que não se vê, e, assim procedendo, o homem corre o risco de errar.

Ao afirmar que a sensação era o critério da verdade, Epicuro estava convicto de que a objetividade da sensação era garantida pela própria estrutura metafísica dos seres, que, segundo a doutrina de Demócrito, era constituída de átomos. Epicuro fez sua esta doutrina. Para ele, a física e a teoria do conhecimento mutuamente se implicavam. Os sentidos não se enganavam e o segredo da absoluta veracidade das sensações encontrava-se na sua estrutura "a-racional", livre das deformações dos juízos. Na sensação, tudo se resume a um simples registro. Nelas e por elas, recebemos os átomos dos objetos percebidos, e este registro não poderia ser falso, senão nada seria verdadeiro.

Este primado gnosiológico da sensação, no entanto, não enclausurava Epicuro no mundo do sensível. Com base nas sensações passadas, ele ensinava que se podia, por antecipação $(\pi \rho \circ \lambda \eta \psi i \varsigma)$, apreender sensorialmente um objeto, mesmo quando este não estava presente, salvaguardando, desse modo, a possibilidade dos conhecimentos e dos conceitos inteligíveis. A $\pi \rho 0 \lambda \eta \psi 1 \varsigma$ (antecipação, prenoção) era um correspondente sensitivo do conceito, ou da representação psíquica das coisas. Ela nascia das percepções, era formada pelas repetições dessas percepções e se conservava na memória. Com ela também se articulavam os nomes, que são as expressões fonéticas de nossas percepções. Por causa desta ligação com as percepções, os nomes e, de modo geral, a linguagem revelavam a natureza das coisas. 


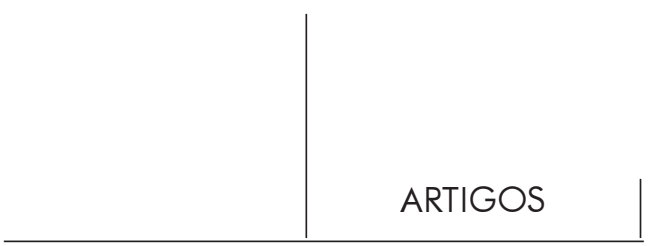

Um outro importante critério da verdade eram os sentimentos $(\pi \alpha \theta \eta)$ de prazer e de dor. Eles não só distinguiam entre o verdadeiro e o falso, mas eram também critérios de escolha, pois distinguiam o bem e o mal e eram, assim, a regra de nosso agir. ${ }^{14}$

O mundo de Epicuro

Embora inspirado na filosofia de Demócrito de Abdera, a concepção do atomismo que Epicuro colocou na base de sua visão do mundo era própria e original. Para ele, os átomos são pesados e se movimentavam de cima para baixo. Os agregados dos átomos e o sistema desses agregados, que formavam o Mundo, seriam inexplicáveis, se os átomos caíssem todos numa trajetória paralela e numa mesma velocidade infinita e sem colisões. Se assim fosse, nenhum mundo surgiria. Para que houvesse Mundo, seria preciso que os átomos se chocassem e se aglomerassem. Donde a necessidade de pequenos desvios na trajetória vertical da queda. A esse fenômeno Epicuro deu o nome de clinamen ou "desvio" ( $\pi \alpha \rho \varepsilon \gamma \kappa \lambda \imath \sigma \imath \varsigma) .{ }^{15}$ Sem esse "desvio" coisa alguma teria sido criada. A efetivação de nosso mundo, como esclarece José Américo Motta Pessanha, dependia da introdução de um mínimo de alteração no cenário cósmico da queda dos átomos. Isso se fazia necessário, a fim de que a possibilidade de um mundo qualquer se tornasse a realidade desse nosso mundo, em particular. A singularidade efetiva era assim atribuída a um desvio (mínimo) do modelo racional que lhe servia de sustentação. ${ }^{16}$

É importante ainda lembrar que, por causa da indeterminação essencial do declínio, o encontro dos átomos formadores das figuras dos seres, era inteiramente fortuito, fruto do puro e mero acaso. Não havia lugar para a idéia de finalidade na filosofia de Epicuro. Os átomos que constituíam o corpo eram a casa dos átomos que formavam a alma. Enquanto o homem vivia, havia interação entre esses dois agregados de átomos: os do corpo e os da alma.

Finalmente, por mais estranho que pareça, havia lugar para os deuses no atomismo materialista de Epicuro. Este justificava a existência dos seres imortais, dizendo que eles, também formados de átomos, eram o resultado de uma prolepsis comum a toda a humanidade. Os deuses também respondiam à intuição que todos

14. Para maiores informações sobre a filosofia de Epicuro, remeto o leitor ao volume III da História da filosofia antiga..., de Giovanni Reale, loc. cit., a quem devo o essencial do resumo aqui apresentado.

15. Veja-se sobre isto o que escreve Léon Robin, com a maestria que lhe é própria, no seu livro $L a$ pensée grecque..., loc. cit., p. 396.

16. José Américo Motta Pessanha. As delícias do Jardim. In Adauto Novaes (org.). Op. cit., p. 71. 


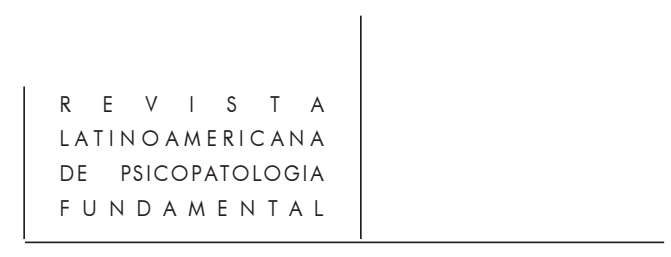

temos de uma existência imortal e feliz. Assim fazendo, Epicuro esboçava um argumento que santo Anselmo, os escolásticos medievais e o próprio Descartes elaboraram, séculos depois, para provar a existência de Deus.

Mas não é meu propósito fazer um estudo detalhado da teoria do conhecimento nem da teoria da natureza de Epicuro. Quero tão-somente mostrar como, baseado nelas, ele ofereceu uma nova orientação ao filosofar e um novo ethos aos homens desorientados de seu tempo.

\section{O culto de Tiché}

Como já sabemos, o tempo de Epicuro foi um tempo particularmente difícil por causa daquele desmoronamento total dos valores transcendentais que marcou a passagem do período helênico para a era helenística. As leis que regiam a vida das antigas cidades independentes foram substituídas pelas decisões pessoais do grande monarca. Tornaram-se, desse modo, leis impostas, diante das quais o indivíduo não tinha outra saída senão obedecer. As leis não podiam mais ser discutidas nas assembléias, como se fazia antes na Grécia Clássica. No imaginário do povo, elas surgiram como se fossem a expressão de uma grande "fatalidade", ou a inexorável realidade do Destino.

Não é, pois, de admirar que, neste contexto, tenha começado a proliferar, na

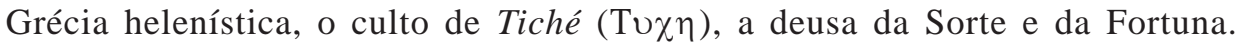
Etimologicamente, a palavra Tu $\chi$ (Tiché) significa o acaso e a sorte e se relaciona também com o Destino (Morpo - Moira). Mas, enquanto a Moira era a parte que cabia a cada um, designada por aquela deusa que estava acima de todos os homens e de todos os deuses e representava o destino inteiramente cego e dominado pela

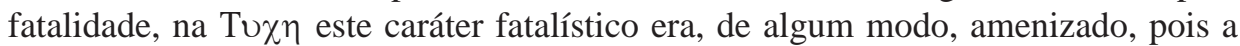
sorte, decretada por Tiché, dependia do modo como o homem se comportava, ${ }^{17} \mathrm{e}$ de inúmeras outras crendices, que, segundo Epicuro, faziam a infelicidade da humanidade.

\section{O lógos terapêutico}

O surpreendente era que, não obstante todas essas dificuldades, Epicuro não cedeu ao pessimismo de seu tempo e ensinava que os homens nasceram para ser felizes e que a felicidade habitava no interior de cada um deles. Para conseguir isto, a filosofia precisava assumir sua função terapêutica, sem a qual seria tão inútil quanto

17. Sobre o sentido da palavra Tiché, ver o que escreve Junito Brandão no Dicionário míticoetimológico. Petrópolis, Vozes, 1992, vols. I e II, pp. 449-450. 


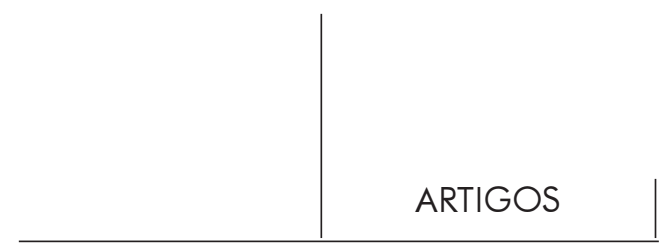

uma medicina que não curasse seus doentes. O lógos filosófico, enquanto remédio ( $\varphi \propto \rho \mu \alpha \kappa o v)$, curava na medida em que afastava as trevas das crenças e expulsava os males da alma. Daí a necessidade de determinar quais eram essas crenças e quais eram esses males. Dir-se-ia que esta era a função diagnóstica do filósofo. ${ }^{18}$ Esta função terapêutica da filosofia não foi uma novidade introduzida por Epicuro. Sócrates a assumiu plenamente e Platão, para definir a missão que seu mestre Sócrates dizia ter recebido do deus Apolo, designou-a com a feliz expressão de uma "terapia da alma". ${ }^{19}$

\section{As crenças}

Como já foi visto, a sociedade do tempo de Epicuro era uma sociedade doente. Os homens acreditavam que era preciso muito dinheiro, luxúria e fama para alguém poder ser feliz. O medo da morte e do sofrimento estava plantado em seus corações. Toda a miséria humana era causada pelas falsas crenças e pelos desejos sem limites, que nelas eram fundados. Epicuro partia da pressuposição de que a sociedade humana era corrompida e era sua influência que corrompia os homens e os fazia miseráveis.

As crenças que mais faziam os homens infelizes eram o medo dos deuses, o medo do sofrimento e o medo da morte. Para curá-los dessas crenças, o filósofo dispunha de um $\tau \varepsilon \tau \rho \alpha \varphi \alpha \rho \mu \alpha \kappa o v$ (tetrapharmakon), ou seja, de um quádruplo remédio: não há nada a temer quanto aos deuses, não há nada a temer quanto à morte, a dor é suportável e a felicidade está ao alcance de todos.

1. Não se deve temer os deuses, porque eles não se ocupam nem se preocupam com os homens, como imagina o povo, nem são os artífices do mundo como pensam os filósofos. Eles existem porque a natureza imprimiu suas pré-noções e imagens ( $\pi \rho \circ \lambda \varepsilon \psi \varepsilon i \varsigma)$ em nossas almas, mas eles não são como nós os representamos ou imaginamos. Por isso, não se deve temê-los e muito menos temer seus castigos.

2. Não se deve temer a morte, porque nada mais absurdo do que o medo da morte, uma vez que ela não é outra coisa senão uma instantânea dissolução dos átomos que constituem nosso ser e isto é inteiramente insensível. O que amedronta os mortais é imaginar a passagem da vida para a morte, mas essa passagem não tem sentido, pois não existe um além-da-morte. Esta acontece num instante, e,

18. Sobre a função diagnóstica na filosofia epicurista, veja-se o que Martha Nussbaum escreve no capítulo IV (Epicurean surgery: Argument and empty desire) do seu belo livro The Therapy of Desire. Theory and Practice in Hellenistic Ethics. Princeton, New Jersey: Princeton University Press, 1994, pp. 102-139.

19. Cf. Platão. Laques, 186 d-e. 


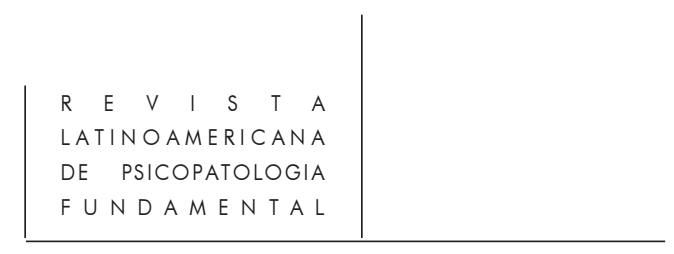

nesse instante, a vida termina e nada mais se pode sentir. Inútil, pois, a preocupação com a morte: "enquanto somos, ela não existe, e quando ela chegar, nós nada mais seremos". ${ }^{20}$

3. A dor pode ser suportada. O grande mal que ameaça a existência dos mortais é indiscutivelmente a dor, pois a $\alpha \pi$ ovı $\alpha$ (ausência de dor) é o segredo da felicidade. Mas Epicuro acredita que se pode facilmente desprezar esta ameaça, porque os sofrimentos mais intensos têm breve duração e, se persistem por muito tempo, causam a morte. Ora, como já foi dito, da morte nada há que se temer. Quanto aos pequenos sofrimentos, esses são facilmente suportáveis. ${ }^{21}$

4. Pode-se alcançar a felicidade, porque o prazer quando buscado corretamente está à disposição de todos.

\section{O prazer na ética de Epicuro}

Vencidos os medos que perturbam a alma, Epicuro, então, ensina que é no prazer $(\eta \delta o v \eta)$ que se encontra o segredo da felicidade. E temos, aqui, o conceitochave da ética de Epicuro. O que Platão e Aristóteles, cada qual a seu modo, viam no sumo Bem como fim último da vida e segredo da felicidade, Epicuro via no prazer. Não é de admirar, portanto, que ele tenha feito do prazer o começo ( $\alpha \rho \chi \eta)$ e o fim ( $\tau \varepsilon \lambda \circ \varsigma$ ) da vida feliz ( $\tau \circ \cup \mu \alpha \kappa \alpha \rho ı \varsigma \zeta \eta \nu$ ), e que, nele, tenha visto "o mais conatural" e o "maior de todos os bens", o "bem primeiro" ( $\alpha \gamma \alpha \theta \circ v \pi \rho \omega \tau \mathrm{ov}){ }^{22}$

Mas, como observa Léon Robin, ${ }^{23}$ o prazer, na sua forma mais perfeita, é aquele que elimina todo sofrimento. O homem procura o prazer, sobretudo, quando a sua ausência causa sofrimento. Quando não sofre, ele não sente falta do prazer. Sem dúvida, já existe prazer na procura do prazer. Beber água, por exemplo, quando se está com sede, é uma atividade que já é prazerosa, mas o verdadeiro prazer só se realiza quando a sede é saciada.

Daí a distinção fundamental que Epicuro estabelecia entre o "prazer em repouso" ( $\eta \delta$ ov $\eta \kappa \alpha \tau \alpha \sigma \tau \eta \mu \alpha \tau 1 \kappa \eta)$, ou seja, o prazer vivido na paz e na tranqüilidade do

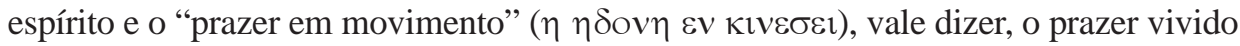
na agitação da alma ou no afã da procura. Epicuro subordinou esta última forma de prazer à primeira, porque nada é prazeroso se não for vivido na ausência da dor $(\alpha \pi \circ v i \alpha)$ e na paz do espírito $(\alpha \tau \alpha \rho \alpha \chi \imath \alpha)$.

20. Epicuro. Epístola a Meneceu, 124.

21. Epicuro. Sentenças Vaticanas, 4. Sobre este tetrapharmakon ver o que escreve José Américo Motta Pessanha no seu belo artigo "As delícias do Jardim". In Adauto Novaes (org.). Op. cit. 22. Usener, p. 6, 23. Apud Nemesius Gonzales Caminero, op. cit., p. 40.

23. Léon Robin, La pensée grecque..., loc. cit., pp. 401-402. 


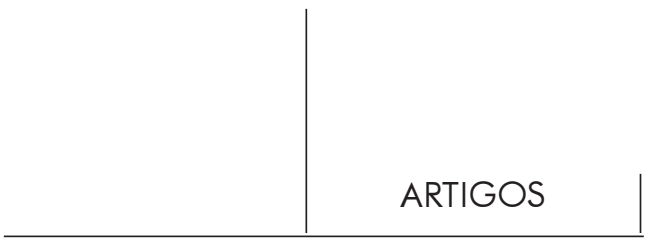

Por causa do primado gnosiológico dado pelo epicurismo às sensações, difundiuse, entre os filósofos da era helenística, a idéia que Epicuro só valorizava os prazeres obtidos pelos sentidos. Tendo afirmado, certa vez, que o "prazer do ventre" ( $\eta \delta$ ov $\eta$ $\tau \eta \varsigma \gamma \alpha \sigma \tau \rho \circ \varsigma)^{24}$ era o "início" e a "raiz" de todo bem, ele provocou a reação hostil de muitos filósofos, entre os quais se destacaram Plutarco, Sêneca, Cícero e, mais tarde, santo Agostinho.

No entanto, Epicuro não só não desconheceu, mas deu um lugar de destaque aos prazeres do espírito. Para tanto, basta lembrar o lugar que tinham "os átomos da alma" na sua filosofia e do seu papel na formação de nossos sentimentos e de nossa vontade. Depois, é preciso não esquecer que, para Epicuro, a lembrança de alegrias passadas podia afastar um sofrimento presente. No último dia de sua vida, ele dizia que a lembrança das conversas tidas com um amigo aliviava as dores terríveis que afligiam seu corpo.

Fonte de prazer espiritual, era também a amizade $(\varphi \imath \lambda \imath \alpha)$ praticada no Jardim. Segundo o insuspeito testemunho de Cícero, nada existia de mais agradável, para Epicuro, do que a amizade. Para se viver bem, nada maior (nihil maius), nada mais fecundo (nihil uberius), nada mais agradável (nihil jucundius) do que a amizade, e tudo isso ele o comprovou não só com as palavras, mas muito mais com a vida, os fatos e os costumes (vita et facto et moribus). ${ }^{25}$ Não era impossível, portanto, que alguém encontrasse mais prazer na amizade do que nos prazeres dos sentidos. $\mathrm{O}$ importante era que o prazer prevalecesse, fosse ele sensitivo ou de natureza espiritual.

\section{A prudência}

O sábio epicurista utilizava a prudência ( $\varphi \rho \circ \vee \eta \sigma ı \varsigma)$ como um excelente instrumento para ordenar a vida, para renunciar aos prazeres imediatos, em vista de prazeres mais compensadores e não deixava que os prazeres em movimento roubassem a paz e a tranqüilidade da alma, sem as quais não era possível a experiência do prazer. Precisamente porque o prazer era o "o bem primeiro" ( $\alpha \gamma \alpha \theta \circ \nu \pi \rho \omega \tau \circ \nu)$, o homem podia e devia se privar do prazer, quando este podia ser causa de sofrimento. E o próprio sofrimento podia, por sua vez, ser preferido ao prazer, se dele se podia esperar um prazer maior e mais duradouro.

Esta foi a razão pela qual a phronesis ocupou um lugar de realce na ética de Epicuro. Nela e com ela, os gregos podiam dispor daquilo que tanto valorizavam, ou seja, da "mensuração comparativa" ( $\sigma u v \mu \varepsilon \tau \rho \eta \sigma ı \varsigma)$, critério de grande valia para a retidão das escolhas. Já sabemos a importância que tinha a idéia de métron (medida)

24. Usener, frag. 409. Apud Nemesius Gonzales Caminero, op. cit., p. 41.

25. Cicero. Cf. Usener, frag. 539. Apud Nemesius Gonzales Caminero, op. cit., p. 42. 


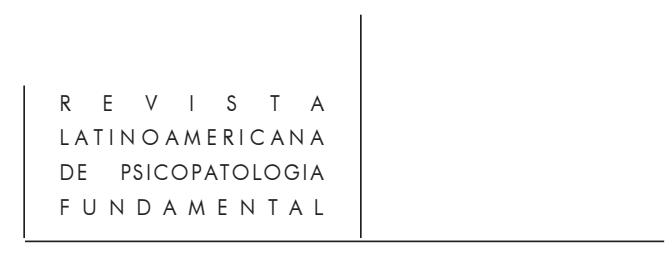

para a Weltanschauung helênica. Isto aparece claramente na carta escrita a Meneceu, na qual se lê que as virtudes são congênitas a uma vida prazerosa. ${ }^{26} \mathrm{E}$, no fim da carta, Epicuro afirma solenemente: "Quem assim procede, vive como um deus entre os homens ( $\omega \varsigma \theta \varepsilon \circ \varsigma \varepsilon v \alpha v \theta \rho \omega \pi \mathrm{ol \varsigma}$ ), pois não é semelhante a um mortal, quem vive entre bens imortais" ( $\varepsilon v \alpha \theta \alpha v \alpha \tau$ ors $\alpha \gamma \alpha \theta 01 \varsigma) .{ }^{27}$

Vejamos, agora, o que se dizia, no Jardim de Epicuro, sobre os desejos e qual o lugar que tinha o desejo no novo ethos que Epicuro ofereceu aos homens de seu tempo.

\section{Os desejos}

Antes de mais nada, é preciso ter presente uma distinção fundamental que Epicuro estabeleceu entre os desejos vazios ( $\kappa \varepsilon v \alpha \imath \varepsilon \pi \imath \theta u \mu l \alpha \imath)$ e os desejos naturais ( $\varphi \vee \sigma \imath \kappa \alpha \imath \varepsilon \pi \imath \theta \cup \mu \imath \alpha \imath)$, pois sua concepção do desejo é inteiramente diferente quando se trata desses ou daqueles desejos. Os desejos vazios são olhados de modo inteiramente negativo, pois são a maior fonte de perturbação interior. Eles são motivados por uma demanda sem-limite que condena os homens a uma procura sem fim e sem sossego. São eles: a riqueza, o poder, e o desejo de imortalidade, cuja posse, ou é impossível, ou jamais pode assegurar uma satisfação estável.

Em contraposição, os desejos naturais são aqueles que brotam espontâneos de uma natureza não corrompida pelas crenças. Antes de receber as más influências da sociedade, a natureza, como a criança, não é corrompida. Seus desejos não são excessivos, são naturalmente limitados e não são motivados por demandas impossíveis. ${ }^{28} \mathrm{O}$ objetivo desses desejos e dos prazeres que lhes são unidos é a eliminação da dor. Esta, uma vez alcançada, o prazer não cresce ulteriormente, nem o desejo angustia o homem. ${ }^{29}$ Assim considerado, o desejo é inseparável do prazer e seu lugar na ética de Epicuro é fundamental.

O desejo natural de comer, por exemplo, pode satisfazer-se com uma modesta quantidade de comida. Não é o estômago que é insaciável, mas a falsa crença, segundo a qual o estômago precisa de uma quantidade excessiva para satisfazer-se. A natureza foi sábia, diz Epicuro, porque tornou fáceis as coisas de que temos necessidade e difíceis as que não são necessárias. "Os bens da natureza são facilmente encontráveis, porque a natureza contenta-se com pouco". ${ }^{30}$ Ora, "para

26. Usener, p. 64, 12. Apud Nemesius Gonzales Caminero, op. cit., p. 42.

27. Id., ibid.

28. Estobeu, Anthol., III, 17, 33, 501. (Usener, frag. 181). Apud Giovanni Reale. História da filosofia antiga. Os sistemas da era helenística. Loc. cit., p. 214.

29. Epicuro, Máximas capitais, 3 e 18. (Usener, frag. 454 e seguintes). Apud ibid., p. 214.

30. Cicero. De Fin., II. 28, 9. Apud ibid., p. 214. 


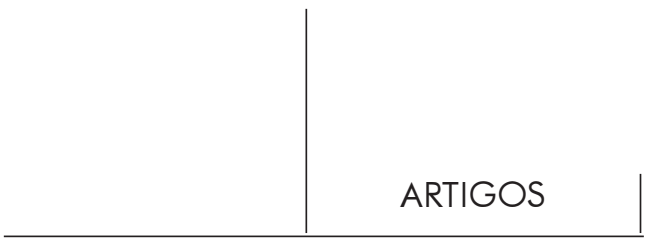

quem pouco não basta, nada basta". ${ }^{31}$ Quando olhada na perspectiva dos desejos naturais, "a riqueza está toda compreendida em pão, água e um pequeno conforto para o corpo". Mas na perspectiva dos desejos vazios, "a riqueza supérflua dá à alma uma ilimitada prova de desejos". ${ }^{32}$ E Epicuro conclui dizendo que "nada é tão necessário quanto saber reconhecer o que não é necessário". ${ }^{33}$

Todavia, ao lado dos desejos vazios, que não são nem naturais nem necessários, existem desejos naturais que são necessários e desejos naturais que não são necessários. Os desejos naturais e necessários são indispensáveis para tornar a vida alegre e agradável. Eles são uma das fontes do prazer tranqüilo ( $\eta \delta$ ov $\eta$ $\kappa \alpha \tau \alpha \sigma \tau \eta \mu \alpha \tau \iota \kappa \eta)$ que é o princípio e o fim da vida feliz. A satisfação dos desejos naturais e necessários é indispensável, porque, sem ela, a dor não desaparece, e só quando a dor desaparece, o prazer encontra seu ápice, pois, o segredo da felicidade está na ausência da dor $(\alpha \pi \circ v \imath \alpha)$. Daí resulta que o desejo natural e necessário é inseparável do prazer, e isso lhe assegura um lugar central na ética de Epicuro.

Os desejos que são naturais e que não são necessários, por serem desejos em movimento, são muito mais fontes de preocupações para a alma do que de tranqüilidade e, por isso, não fazem o homem mais feliz. Ao que tudo indica, foi nesta categoria que Epicuro colocou os desejos sexuais. ${ }^{34}$

Os desejos sexuais

É ambivalente a atitude de Epicuro diante dos desejos sexuais e do amor erótico, pois se, algumas vezes, ele afirma que "não poderia ser feliz quem renunciasse aos prazeres do odorato, do sexo ( $\alpha \varphi \rho \circ \delta ı \sigma \imath v)$, da audição e das belas formas", 35 em outras ocasiões ele é categórico, quando afirma que a relação sexual "nunca traz benefício" e que "devemos contentar-nos com que não traga prejuízos". ${ }^{36}$ Sorte, portanto, daquele a quem ela não traz preocupação. ${ }^{37}$ Por isso, Epicuro aconselha

31. Eliano, Varia Hist. IV, 13. Apud ibid., (1994), p. 215, nota 31.

32. Usener, frag. 471. Apud ibid., p. 214.

33. Porfírio, Ad Marcellam, 28, p. 292. Apud ibid., p. 215, nota 34.

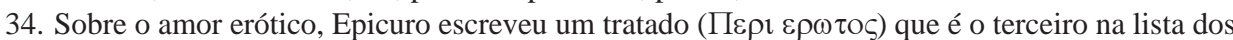
seus tratados, feita por Diógenes Laércio. O que Epicuro diz sobre o desejo sexual é trabalhado detalhadamente por Martha Nussbaum em seu livro The Therapy of Desire, loc. cit., p. 154.

35. Diógenes Laércio, frag. 67. Apud Nemesius Gonzalez Caminero, op. cit., p. 41.

36. Diógenes Laércio, X, 118. (Usener, fr. 62). Apud Giovanni Reale. História da filosofia antiga. Os sistemas da era helenística. Loc. cit., p. 213.

37. V. S. 51. Na tradução de Martha Nussbaum: "For sexual intercouse never did any good, and it's lucky if it does no harm". Cf. Martha Nussbaum, op. cit. p. 151. 


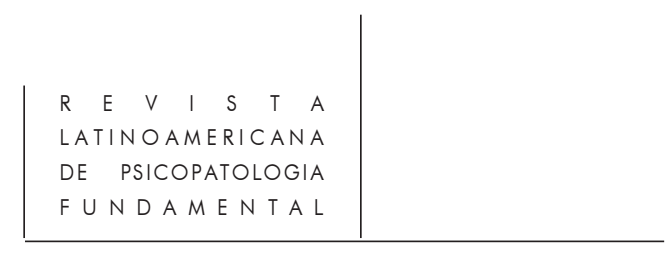

os jovens a se afastarem dos desejos e dos prazeres do sexo, pois eles são angustiantes. Eles, portanto, fariam parte daqueles desejos que embora sejam naturais, não são necessários. Mais ainda: o desejo sexual seria uma "corrução" ou "perversão" do impulso instintivo, que brota espontâneo da própria natureza e que, por isso mesmo, conhece seus limites. Pervertido pela crenças, o instinto natural torna-se, enquanto desejo sexual, causa de preocupação e de angústia.

\section{O sábio epicurista}

Quando, pelo lógos filosófico, o homem não se deixa seduzir pela ilusão dos desejos e dos prazeres que não são nem necessários nem naturais e se liberta dos medos que perturbam a alma, ele adquire a sabedoria e, com ela, a autarquia do sábio. Esta é a sua maior riqueza. Livre dos desejos inúteis, dos medos e das preocupações da vida em sociedade, o sábio epicurista "vive escondido", ou melhor, vive recolhido dentro de si mesmo na paz interior da alma $(\alpha \tau \alpha \rho \alpha \xi \downarrow \alpha)$, onde encontra o segredo da felicidade.

Uma máxima de Epicuro tinha a força de um oráculo para os seus discípulos: "Vive escondido" $(\lambda \alpha \theta \varepsilon \beta 1 \omega \sigma \alpha \varsigma) .{ }^{38}$ No Jardim, cultivava-se a vida recolhida e se fugia da vida agitada no meio da multidão. Epicuro exprimiu isso admiravelmente, quando escreveu a um dos seus discípulos: "Estas coisas são para ti e não para a multidão, pois já somos um grande teatro um para o outro". 39

\section{No Pórtico Antigo de Zenão e Crísipo}

Os historiadores da filosofia distinguem três etapas na história do estoicismo: O estoicismo antigo (séculos III-II a.C.), o médio estoicismo (século I a.C.) e o estoicismo tardio (séculos I-III d.C). Zenão foi o fundador do estoicismo antigo. Não sendo um cidadão ateniense, pois era natural da Ilha de Chipre e descendente de fenícios, não lhe foi permitido abrir uma escola dentro de Atenas, por isso ele a fundou nas portas da cidade, no Pórtico decorado com as pinturas de Polignoto. Pórtico, em grego, se diz $\Sigma \tau$.o $($ Stoa), por isso aqueles que freqüentavam a escola do Pórtico foram chamados: "os de Stoa", ou seja, os $\Sigma \tau \omega \imath \kappa o l$ (estóicos). Crísipo é considerado o segundo fundador do Pórtico Antigo, uma vez que foi ele quem sistematizou, melhor do que o próprio Zenão, a doutrina do estoicismo antigo.

38. Cf. Usener, frag. 551. Apud Nemesius Gonzalez Caminero, op. cit., p. 44.

39. Hermann Usener, op. cit., frag. 207. 


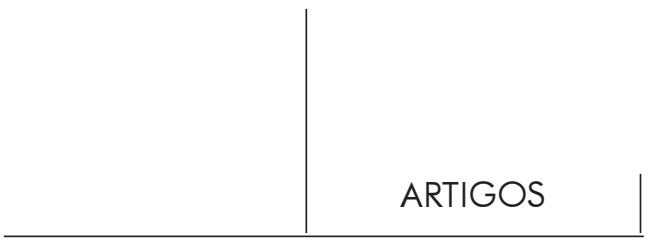

Do Jardim ao Pórtico: convergências e divergências

Há continuidade e descontinuidade, convergências e divergências na passagem do Jardim de Epicuro ao Pórtico Antigo de Zenão e Crísipo. ${ }^{40}$ A linha de continuidade é mantida porque no Pórtico Antigo, como no Jardim de Epicuro, a filosofia é, antes e acima de tudo, uma "forma de vida", uma "arte de viver"; hoje, diríamos: uma "estilística da existência". Na verdade, o estoicismo antigo floresceu marcado pelo mesmo clima cultural em que surgiu e se desenvolveu o epicurismo. Embora as duas escolas, na tentativa de responder às exigências do novo Zeitgeist, tivessem se empenhado em oferecer uma nova proposta ética aos cidadãos gregos, desnorteados pelas mudanças radicais das estruturas socioculturais de seu tempo, na realidade elas apresentaram duas visões de mundo (Weltanschauungen), quase antagônicas, dois modos diferentes de conceber o mundo, o homem e a ética.

Eis algumas das principais divergências. Enquanto o Epicurismo voltava, de modo quase exclusivo, sua atenção para o indivíduo e pouco, ou quase nada, se preocupava com a res publica nem com o universalismo que se instaurou como uma das características mais importantes dos novos tempos, o estoicismo, por uma exigência intrínseca de sua visão de mundo, ressaltava a harmonia cósmica universal, o que significava: os homens deviam estar em paz não só consigo mesmos, mas também com os outros homens, seus concidadãos, e com toda a humanidade. Esta preocupação com o universalismo era uma marca da doutrina filosófica do Pórtico Antigo e se manifestava tanto na lógica, quanto na física e na ética que Zenão e Crísipo elaboraram.

Quanto ao homem, os estóicos não aceitavam que ele fosse reduzido a um aglomerado de átomos, como queriam os epicuristas, mas, inspirados pela filosofia de Heráclito, eles fizeram do Lógos divino, corporificado no fogo, a arché originária de todas as coisas, e, por conseguinte, a explicação última do homem, cuja alma aparece, assim, como tendo a mesma natureza que os deuses.

Mas a divergência maior e mais importante entre as duas escolas é o modo como cada uma define sua proposta ética. Para os epicuristas, como já sabemos, o fim último da vida é o prazer ( $\eta \delta$ ov $\eta$ ) e tudo o mais, inclusive a virtude ( $\alpha \rho \varepsilon \tau \eta)$ é

40. Os fragmentos de Zenão, bem como os de todos os estóicos antigos, foram recolhidos e sistematizados por Hans Arnim no livro Stoicorum Veterum Fragmenta (SVF). Os do médio estoicismo foram editados por L. Edelstein e I. G. Kidd (Cambridge, 1972). Dos grandes pensadores da última fase do Pórtico, em Roma (Sêneca, Epicteto e Marco Aurélio), conservaram-se mais do que fragmentos de suas obras. Mas não é nosso propósito estudar essas três fases do estoicismo. Vamos recordar, apenas, o essencial da doutrina estóica do Pórtico Antigo para melhor situar o que nela foi dito sobre as paixões e o desejo. 


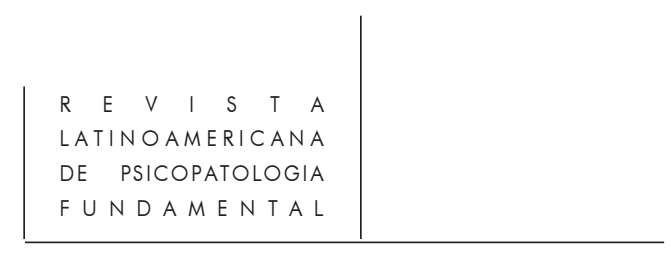

um meio para a consecução deste fim. Os estóicos, pelo contrário, fazem da virtude o fim último da vida. A virtude, por si só, é capaz de nos fazer felizes, e é, portanto, o segredo da felicidade (eudaimonia). ${ }^{41}$

No que se refere à questão das paixões e do desejo, os estóicos adotaram uma atitude negativa muito mais radical e intolerante do que a dos epicuristas. No Jardim de Epicuro, como vimos, devia-se cuidar para que os "desejos vazios" não perturbassem a paz da alma. Os estóicos, como veremos melhor depois, partindo da premissa de que as paixões e os desejos são uma "perversão da razão", ou são frutos de "falsos juízos", exigiam que os desejos e as paixões, melhor do que apenas cuidados, ou terapeuticamente tratados, fossem completamente extirpados. O ideal ético dos estóicos do Pórtico Antigo não era só a paz da alma $(\alpha \tau \alpha \rho \alpha \chi 1 \alpha)$, mas a insensibilidade $(\alpha \pi \alpha \theta \imath \alpha)$ diante da dor e das adversidades.

\section{A filosofia do Pórtico Antigo}

Devo lembrar que não é meu propósito fazer, aqui, um estudo detalhado da doutrina filosófica dos estóicos do Pórtico Antigo que, como os epicuristas, também dividiram a filosofia numa lógica referente ao conhecimento, numa física concernente à concepção do mundo e numa ética, voltada para definir a felicidade do homem nesta vida. Vou, apenas, indicar alguns elementos-chaves, tanto da lógica quanto da física, na medida em que eles se articulam com a doutrina ética, e, na ética, vou dar especial destaque ao que foi dito sobre as virtudes e sobre as paixões, pois é só quando nos falam das paixões que os estóicos focalizam a questão do desejo. Todavia, o que no Pórtico Antigo se disse sobre o desejo foi reformulado depois pelos grandes pensadores do médio estoicismo e do estoicismo na Idade Imperial.

\section{A lógica}

A filosofia dos estóicos é inteiramente dominada pela noção fundamental do Lógos. Este "é o princípio da verdade na lógica, o princípio criador do cosmo e o princípio normativo na ética." ${ }^{42}$ É precisamente esta presença do Lógos que faz da Lógica do Pórtico Antigo não só um critério de verdade (como era a lógica ou canônica epicurista), mas uma verdadeira dialética.

Situado no mundo, o filósofo, para responder ao problema da vida e da existência, deve dispor de instrumentos adequados, capazes de lhe possibilitar o conhecimento da verdade. Daí a necessidade de uma Lógica que oriente a reta maneira

41. Cf. Cicero, De finibus (V, 79). Apud Nemesius Gonzalez Caminero, op. cit., p. 81.

42. Giovanni Reale. História da filosofia antiga.Os sistemas da era helenística. Loc. cit., p. 273. 


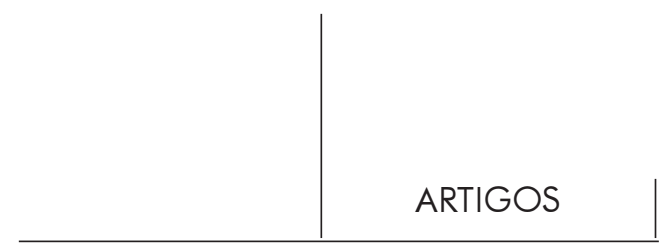

de pensar e o conhecimento da verdade. Além do mais, se a felicidade está na virtude, o homem virtuoso é aquele que é excelente não só na maneira de agir, mas também na maneira de pensar. Todavia, a excelência do pensar só se consegue quando se está de posse da verdade. Por isso era também importante, para os estóicos, elaborar uma lógica e uma dialética que lhes assegurassem a certeza de quem conhece a verdade. $^{43}$

\section{Da sensação \\ à representação compreensiva}

O conhecimento se faz no ritmo de um processo gnosiológico que começa com a sensação $(\alpha \imath \sigma \theta \eta \sigma \imath \varsigma)$. Esta resulta da impressão que os objetos fazem sobre nossos sentidos. Uma vez captada pelos sentidos, a impressão dos objetos é transmitida à alma sob a forma de uma representação $(\varphi \alpha v \tau \alpha \sigma \curlywedge \alpha)$. Sem se entenderem sobre o modo como a impressão era feita na alma (se por um contato físico ou por uma alteração qualitativa), os estóicos afirmavam que, para ser critério da verdade, esta representação do objeto devia receber o assentimento da alma, e deste modo tornar-se uma representação compreensiva. Surgia assim a representação cataléptica ( $\varphi \alpha \nu \tau \alpha \sigma \imath \alpha \kappa \alpha \tau \alpha \lambda \eta \pi \tau \iota \kappa \eta)$.

Somente mediante este "consentimento", a representação $(\varphi \alpha \nu \tau \alpha \sigma \iota \alpha)$ tornavase cataléptica ( $\propto \alpha \tau \alpha \lambda \eta \pi \tau \imath \kappa \eta)$, ou seja, uma representação compreensiva. O sujeito que cativava o objeto pela representação, de algum modo era também cativado por ele, pois diante da evidência objetiva, o sujeito não podia deixar de dar o seu assentimento. Para os estóicos, portanto, a representação verdadeira implicava não apenas um sentir, mas um consentir. Só quando se dava o consentimento, a representação se tornava compreensiva. E era, nela, que estava o critério da verdade. Como esclarece Giovanni Reale: “o assenso não é, em última análise, senão o ato de reconhecer e de dizer sim à evidência objetiva". ${ }^{44}$

43. Estudos relativamente recentes revalorizaram bastante a lógica dos estóicos. Cf. M. Mnignucci. Il significato della lógica stoica. Bolonha, 1965 e A. Virieux Reymond, La logique et l'épistémologie des stoiciens. Lausanne, 1949. Citados por Giovanni Reale. História da filosofia antiga. Os sistemas da era helenística. Loc. cit., p. 276, nota 3. Para Jacques Chevalier (La pensée antique. Paris: Flammarion, 1955. Tome I, pp. 420-425) a lógica dos estóicos é inovadora

44. Giovanni Reale. História da filosofia antiga. Os sistemas da era helenística.Loc. cit, p. 281. 
Das representações compreensivas aos conceitos universais

A etapa seguinte era a passagem da representação cataléptica individual para as representações universais. Depois que se constituía a representação cataléptica singular, sua lembrança ficava na memória $(\mu \nu \eta \mu \eta)$. Com a repetição desta imagem nas representações semelhantes formava-se a experiência $(\varepsilon \mu \pi \varepsilon i \rho \imath \alpha)$, que derivava da multidão das fantasias semelhantes. Delas, finalmente, procediam os conceitos universais $(\varepsilon v v o r \alpha)$. É precisamente, aqui, que a lógica do Pórtico Antigo supera a lógica epicurista. Enquanto os epicuristas reduziam a lógica ao critério das evidências, que, para eles, era apenas a evidência sensível, os estóicos não se restringiam ao mundo do conhecimento sensitivo e abriam espaço, na sua lógica, para o problema dos universais. E isto permitiu que sua lógica se desdobrasse numa dialética.

Quando coordenadas e sistematizadas, as representações singulares tornavamse conceitos universais ( $\varepsilon v v o r \alpha l)$. Já sabemos que os epicuristas desconfiavam do pensamento que se separava da experiência sensível, pois viam, nele, uma fonte de engano e de erro. Já os estóicos não se contentaram com o conhecimento sensível, embora não tenha sido fácil definir a natureza dos conceitos universais.

No dizer de Sexto Empírico, os estóicos conjugaram, entre si, três coisas, ou seja, a coisa significante $(\sigma \eta \mu \alpha \imath \mu \mathrm{ov} \tau \alpha)$, a coisa significada $(\sigma \eta \mu \alpha \imath \mu \varepsilon v \alpha)$ e a coisa que existe fora do sujeito. As coisas significantes eram as vozes ou as palavras, mediante as quais se dizia o que se queria significar. A coisa significada era o próprio objeto-que-era-indicado pela voz significante, ou o atributo que era indicado ao sujeito. Este objeto que era apresentado pelo pensamento, por meio da voz que o indicava, se fosse ouvido, por exemplo, por um bárbaro que não entendesse o grego, não seria compreendido.

Por fim, a coisa que existia era a que estava fora de nós. Para os estóicos, a coisa significante e a coisa que existia fora de nós eram corpóreas. Incorpórea era a coisa significada, a qual era considerada como verdadeira ou falsa e era atribuída ao sujeito. Esses atributos, porém, não tinham fundamentação na realidade. Eram puros "exprimíveis", ou "dizíveis", que só existiam enquanto relacionados com o dizer $(\lambda \varepsilon \gamma \varepsilon i v)$ e com o pensar. ${ }^{45}$

No Pórtico Antigo, portanto, a dialética se dividia em duas grandes partes: uma concernente ao significado e outra referente ao significante. O significante era a expressão verbal ou as palavras pelas quais se dizia o que se queria dizer, e o significado representava o conteúdo do pensamento, ou aquilo que era dito e atribuído

45. Cf. Sexto Empírico. SVF, II, frag. 166. Apud Giovanni Reale. História da filosofia antiga. Os sistemas da era helenística. Loc. cit., p. 285. 


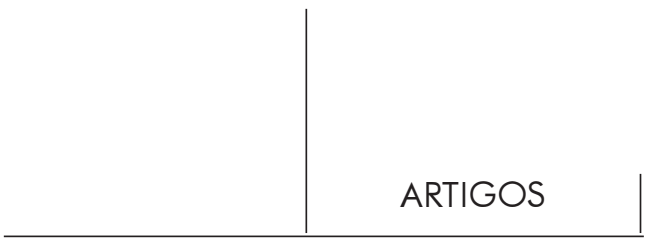

ao sujeito. Por isso, a dialética tratava da linguagem, da palavra e das formas de pensamento. A grande questão que se punha era: como atingir, por meio do signo, a verdade que ele representava, e qual a relação do significado com a realidade?

Resumindo, poder-se-ia dizer que o grande merecimento da lógica e da dialética do Pórtico Antigo foi o fato de estas não terem se confinado no mundo do conhecimento sensitivo, mas terem aberto espaço para o problema dos universais. Compartilhando, porém, com os epicuristas, o dogma de que só as coisas corpóreas eram reais, eles diziam que os conceitos universais eram incorpóreos e, conseqüentemente, destituídos de realidade metafísica, como queriam Platão e Aristóteles.

Esta posição que os estóicos tomaram diante do problema dos universais foi lembrada quando, nos séculos XI e XII, os filósofos medievais se colocaram, de novo, a questão: os conceitos que nossa linguagem utiliza para significar os atributos dos seres, existem na realidade, ou são meras produções de nossa inteligência? Os que assumiram uma posição realista e afirmaram que os conceitos existem na realidade, independentemente de nosso pensamento, apelaram para a metafísica de Platão. Aqueles, porém, que defenderam uma posição nominalista dizendo que os universais eram puros nomes, ou, melhor ainda, aqueles que defenderam uma posição conceitualista, dizendo que os universais eram meros conceitos criados pelo nosso pensamento, esses inspiraram-se na reflexão dos estóicos, que reduziram os universais a meras produções do pensamento, sem nenhuma conotação metafísica nem nenhuma fundamentação na realidade. ${ }^{46}$

\section{O mundo}

O mundo, para os estóicos, era a totalidade da realidade, vale dizer, a $\Phi$ $\sigma \iota \varsigma$ (Physis), como a entendiam os pré-socráticos. Esta maneira de conceber o mundo era totalmente diferente daquela defendida pelos epicuristas, os quais, inspirados no atomismo de Demócrito de Abdera, viam no mundo o resultado fortuito de um aglomerado de átomos. A este mundo, assim construído ao acaso, os estóicos opunham um Mundo inteiramente regido e dirigido pelo lógos, ou seja, pela razão divina.

46. Sobre a questão dos universais, tal como foi colocada pelos medievais, permito-me enviar o leitor ao que sobre isto escrevi nos meus livros: Paixão, violência e solidão. O drama de Abelardo e Heloísa no contexto cultural do século XII. Recife: Editora Universitária da UFPE, 1996, pp. 160-170; e Abelardo-Heloísa. Cartas. As cinco primeiras cartas traduzidas do original e comentadas. Edição bilingüe. Recife: Editora Universitária da UFPE, 1997, pp. 303-304. 


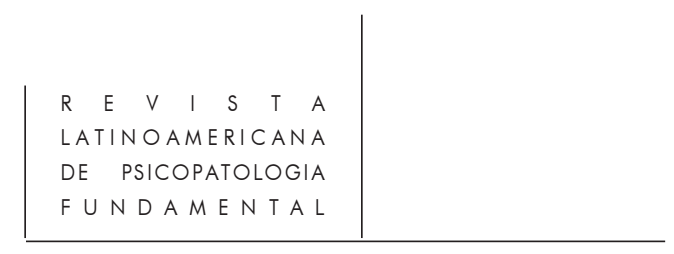

Os estóicos, inspirados em Heráclito de Éfeso, corporificaram o lógos, artífice de todos as coisas, sob a forma do fogo. Como para Heráclito, também para eles, o

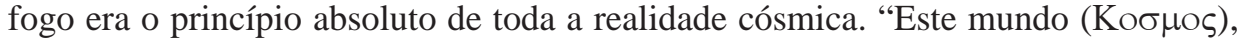
o mesmo de todos, nenhum deus, nenhum homem o fez, mas era, é e será um fogo sempre vivo, acendendo-se na medida e apagando-se na medida". ${ }^{47}$

Dois eram, para os estóicos, os princípios da realidade: um era o fogo, que determinava a matéria, e o outro era a matéria, que era movida e determinada pelo fogo. Portanto, o fogo era a matéria e a causa de tudo o que existia. É o que diz Sêneca nesta passagem: "A matéria jaz inerte, preparada para tudo; a causa, ou seja, a razão dá forma à matéria. Deve, pois, existir algo donde algo se faz e por quem algo se faz; este é a causa, aquele, a matéria". ${ }^{48}$

No fogo temos, portanto, ao mesmo tempo, a matéria e a causa. A causa é o lógos que contém em si as sementes de todas as coisas. Entram em cena, aqui, os

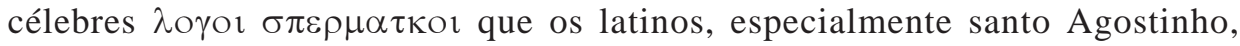
traduziram como "razões seminais" (rationes seminales), e que ocupam um lugar de destaque na explicação estóica do mundo, semelhante ao lugar que têm, em suas respectivas cosmologias, as idéias de Platão e a forma aristotélica.

Se tal era a função metafísica do lógos-fogo, não é de admirar que, para os estóicos, ele fosse Deus, e, ao mesmo tempo, pudesse ser olhado como providência $(\pi \rho v(\alpha)$ e destino $(\varepsilon \uparrow \mu \alpha \rho \mu \varepsilon v \eta)$. Se o lógos-fogo era o princípio imanente de todas as coisas, tudo o que se fazia, obedecia rigorosamente a um plano preestabelecido. Nada existia nem podia existir fora de lugar.

Uma feliz expressão desse finalismo universal é a doutrina estóica sobre a providência. Nenhuma outra escola da filosofia grega formulou tão claramente a doutrina da providência. Mas, como observa Giovanni Reale, não se tratava de uma providência transcendente, mas imanente, nem de uma providência que se preocupasse com os homens individuais, como acontecerá depois com o conceito de Providência na visão cristã do mundo. Para os estóicos, era o mundo que era objeto da providência, que, por isso mesmo, podia também ser vista como a força do destino. ${ }^{49}$

Se todas as coisas - as que aconteceram no passado, as que acontecem no presente e as que acontecerão no futuro - são determinadas pelo lógos, e este lógos é o princípio imanente de tudo o que existe, daí se segue que tudo é necessário,

47. Heráclito de Éfeso, frag. 22.

48. Sêneca, Epist.65, 2. In Hans Arnim. Stoicorum vetera fragmenta. Leipzig: Teubern, 1905. II. 303. Apud Nemesius Gonzalez Caminero, op. cit., p. 57.

49. Giovanni Reale. História da filosofia antiga. Os sistemas da era helenística. Loc. cit., pp. 314316. 


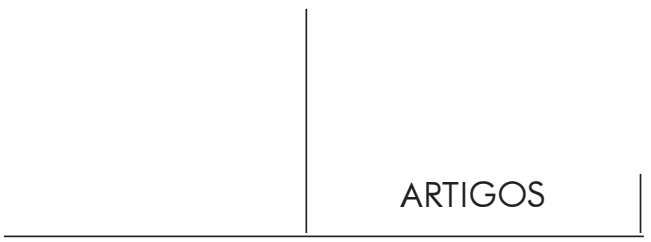

pois tudo tem seu lugar determinado. O Destino ( $1 \mu \alpha \rho \mu \varepsilon v \eta)$ não é outra coisa. Diógenes Laércio o disse explicitamente: "O destino é uma concatenação de causas do que existe, ou a razão (lógos) que dirige e que governa o cosmo". ${ }^{50}$

O preço de semelhante doutrina foi a total ausência, na filosofia dos estóicos, dos conceitos fundamentais de liberdade e de responsabilidade. Só lhes restou, depois de inúmeros esforços para tentar salvar a liberdade, conceber sua possibilidade como "um querer o que quer o destino" e um "levar a vida em total sintonia com o lógos". Nada ilustra melhor a concepção de liberdade dos estóicos do que estes versos de Cleanto:

Guia-me, ó Zeus, e tu, Destino, ao termo,

Qualquer que este seja, que te aprouve atribuir-me.

Seguirei imediatamente, porque se me demoro,

Por ser vil, do mesmo modo deverei alcançar. ${ }^{51}$

Quem melhor interpretou este verso de Cleanto foi Sêneca, quando escreveu: "Ducunt volentem fata, nolentem trahunt", ${ }^{52}$ ou seja, o destino dirige quem o aceita e arrasta quem não o rejeita. Quem não aceita subordinar-se à lei do destino, mais cedo ou mais tarde será por ele dominado, porque ninguém pode escapar ao lugar que lhe foi traçado na ordenação do cosmo.

\section{O homem}

Para os estóicos, a mais importante materialização do fogo, no processo evolutivo da formação do cosmo, era o homem. Ele era um microcosmo e tinha também o duplo princípio (matéria e causa) que se encontrava na origem do mundo. Corpo e alma interagiam de modo muito especial, e a maneira como os estóicos salientavam essa interação não passará despercebida aos psicossomáticos de nossos dias: "A alma compadece-se do corpo que sofre por causa da doença ou das feridas e o corpo se compadece da alma. Se a alma é tocada pela vergonha, o corpo se torna rubro ( $\varepsilon \rho v \theta \rho \circ v)$ e se ela é dominada pelo temor, ele se torna pálido". Donde, concluíam: "A alma era corpo $(\sigma \omega \mu \alpha \alpha \rho \alpha \eta \psi v \chi \eta) " .{ }^{53}$ Mas, nem por isso, a alma

50. Diógenes Laércio, VII, 149. [von Hans Arnim, Op. cit., I, frag. 175]. Apud Giovanni Reale. Ibid., p. 316.

51. Versos apresentados em Epicteto, Manual, 53 [von Hans Arnim. Op. cit., frag. 527]. Apud Giovanni Reale. Ibid., p. 320.

52. Sêneca. Epist. 107, 10. Apud Giovanni Reale. Ibid., p. 320.

53. Nemesius, De nat. hominis, p. 32. [von Hans Arnim. Op. cit., I, 518]. Apud Nemesius Gonzalez Caminero. Op. cit., p. 61. 


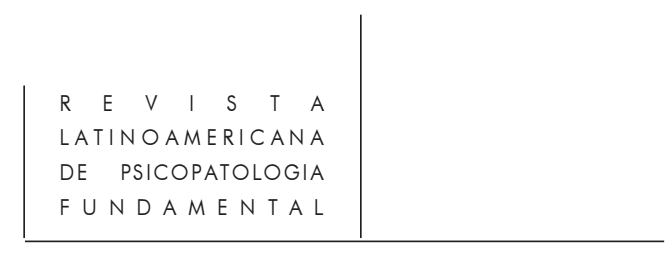

deixava de ser um fragmento da alma do cosmo, e, portanto, um fragmento da alma divina. "Pneuma ígneo", como a chamava Zenão, ${ }^{54}$ ela tinha uma parte principal (o hegemônico) na qual se encontrava a capacidade de raciocinar, perceber e desejar.

O mundo, que foi criado pelo fogo, será destruído pelo fogo, pois tudo o que teve começo terá fim, e se, por um lado, o fogo cria, por outro ele também carboniza e destrói. Por isso, é inevitável que o fogo que tudo cria, um dia tudo destrua. Haverá, assim, uma combustão do cosmo. Mas tudo o que for destruído, será também restaurado num processo de restauração que não terá fim. Depois da destruição universal pelo fogo $(\varepsilon \kappa \pi \imath \rho \omega \sigma \imath \varsigma)$, haverá um novo nascimento $(\pi \alpha \lambda \iota \gamma \varepsilon v \varepsilon \sigma \iota \alpha)$ e tudo será restaurado e voltará a ser como era antes ( $\alpha \pi$ ก $\alpha \tau \alpha \sigma \tau \alpha \sigma \iota \varsigma)$. Tudo o que foi voltará a ser como antes, até nos mínimos detalhes.

\section{A ética dos estóicos}

Os filósofos gregos ressaltaram, de modo muito significativo, a analogia entre a ordem cósmica do mundo físico e a ordem ética do mundo humano. ${ }^{55}$ Nenhuma outra ética, melhor do que a dos estóicos, confirmou a importância desta analogia. Ela se fundamentava metafisicamente no fato de o lógos divino estar presente tanto no vir-a-ser $(\varphi \cup v \alpha \imath)$ do grande mundo, quanto na natureza do pequeno mundo, que é o homem.

Posto isto, facilmente se compreende que, para os estóicos, o objetivo da ética pudesse ser resumido, como fizeram Zenão, Cleonto e Crísipo, nas seguintes fórmulas:

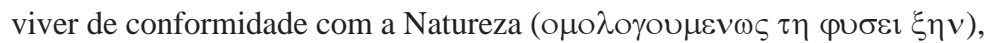

viver de conformidade com a razão ( $\tau$ o $\kappa \alpha \tau \alpha \lambda$ $\mathrm{o} \gamma \mathrm{ov} \xi \eta \nu)$ e

viver segundo a virtude ( $\kappa \alpha \tau \square \alpha \rho \varepsilon \tau \eta v \xi \eta v)$.

Estas fórmulas, elaboradas em momentos diversos da sistematização teórica da doutrina estóica, mutuamente se completavam e se explicavam..$^{56} \mathrm{~A}$ natureza, cujo modelo assegurava a retidão ética do agir humano, era tanto a natureza cósmica regida pelas leis universais, quanto a natureza do homem individual. Uma vez que, nestas duas naturezas, era imanente a presença do lógos, podia-se concluir que viver

54. Zenão. Cf. Diógenes Laércio. VII, 157. [von Hans Arnim. Op. cit., I, frag. 135]. Apud Giovanni Reale. Ibid., p. 325.

55. Cf. Werner Jäger. Paideia. Los ideales de la cultura griega. Trad. espanhola Joaquim Xirau. Mexico: Fondo de Cultura Económica, 1953,Vol. I., 171-206.

56. Uma detalhada análise destas fórmulas é feita por Nemesius Gonzalez Caminero, na sua Historia Philosophiae... Loc. cit., pp. 64-77. 


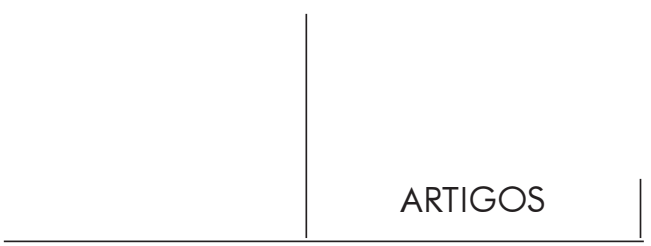

de conformidade com a natureza era a mesma coisa que viver segundo as exigências da razão.

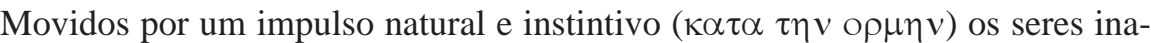
nimados (as árvores) e os irracionais (os animais) entravam em harmonia com o todo do universo e, no centro dessa grande sinfonia cósmica, estava o homem, dotado de razão. Ora, nada mais sublime do que a razão, pois era por meio dela que o homem participava do divino. É o que atesta esta maravilhosa passagem de Cícero:

Portanto, o que - não digo no homem, mas em todo o céu e em toda a terra existe mais divino do que a razão (ratione divinius)? Esta quando atinge a maioridade e se torna perfeita (quae cum adulevit atque perfecta est), convenientemente se chama de sabedoria (sapientia). Portanto, porque nada de melhor existe do que a razão e ela se encontra no homem e em Deus, ela é a primeira sociedade do homem com Deus (prima hominis cum Deo societas). ${ }^{57}$

E Sêneca: "A quem foi dado uma natureza racional, que coisa existe melhor do que a razão?" 58

Mas era quando agia segundo a virtude ( $\alpha \alpha \tau \square \rho \rho \varepsilon \tau \eta v)$ que, finalmente, o homem se conformava com a natureza e obedecia às exigências de sua razão. Portanto, podemos concluir que era no conceito de virtude ( $\alpha \rho \varepsilon \tau \eta)$ que os estóicos fundamentavam a sua proposta ética.

O lugar da virtude na ética dos estóicos

Todos os filósofos da Grécia Antiga deram um lugar de destaque ao conceito de virtude, pois, para eles, era por meio da virtude que se atualizava a perfeição da natureza humana. A virtude era a excelência, no verdadeiro sentido da palavra. $\mathrm{O}$ sapateiro virtuoso era o que fazia, de modo excelente, os seus sapatos, do mesmo modo como o general virtuoso era o que planejava, de modo excelente, as estratégias de seus combates. O homem virtuoso realizava, pois, de modo excelente, as possibilidades da natureza humana. Daí o lugar de destaque que a virtude sempre teve na ética dos gregos.

Todavia, enquanto para os demais filósofos a virtude era apenas um meio embora excelente - para a consecução da felicidade ( $\varepsilon v \delta \alpha \imath \mu \circ v \iota \alpha)$, para os estóicos a virtude era a própria felicidade. Diógenes Laércio resumiu, numa frase, esta maneira

57. Cícero. De Legibus, I. 7, 22. Apud Nemesius Gonzalez Caminero. Op. cit., p. 67. 58. Sêneca. De Vita beata, 13. Apud Nemesius Gonzalez Caminero. Op. cit., p. 67. 


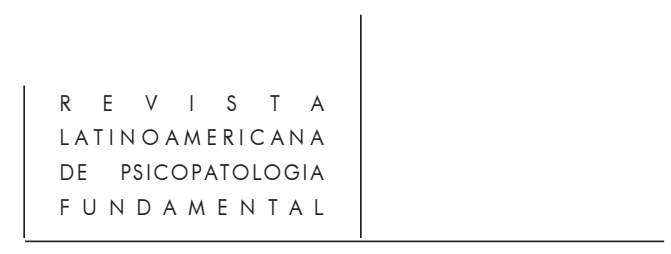

típica dos estóicos conceberem a virtude, como fim último da vida humana."A virtude, escreve ele, é suficiente para nos fazer viver felizes." ${ }^{.9}$

Tanto quanto o sábio, a virtude era também autárquica. Enquanto autárquica, ela não era apenas um "meio", mas um verdadeiro "fim" ( $\tau \varepsilon \lambda \circ \varsigma)$ e era suficiente para nos fazer felizes. Da mesma forma que o sábio não precisava sair de si, nem buscar nada fora de si para ser feliz, da mesma forma a virtude não precisava de nada fora de si, para fazer os homens felizes.

Pouco importa se os teóricos do estoicismo antigo sentiram dificuldade e não conseguiram, de modo unânime, definir a natureza da virtude. O que importa é que, para eles, a virtude podia e devia ser considerada como "o único bem da alma"

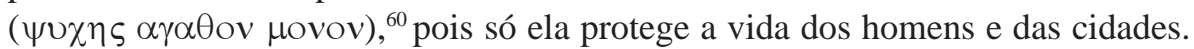

De dois modos os estóicos definiram a natureza da virtude. Uns, seguindo os ensinamentos de Crísipo, viam nela uma reta maneira de pensar. Uma vez que a virtude aperfeiçoava a natureza humana e esta consistia essencialmente na razão e no conhecimento, era, na razão e no conhecimento, que estava a essência da virtude. Mas este intelectualismo exagerado de Crísipo, foi amenizado por Zenão, que via a essência da virtude na "prudência" (phrónesis), antes que na ciência (epistheme).

Embora não seja meu propósito trabalhar detalhadamente esta questão dos estóicos sobre a essência da virtude, acho oportuno lembrá-la, porque ela se articula com o modo como os estóicos se comportavam diante das paixões. Ora, como é no capítulo das paixões que eles nos falam do desejo, é sobre o lugar e o papel das paixões, no contexto da ética estóica, que passarei a tratar em seguida.

\section{As paixões e os desejos na ética dos estóicos}

Em artigos anteriores sobre o desejo na Grécia Arcaica e na Grécia Clássica, ${ }^{61}$ tentei mostrar como, desde Homero, os poetas épicos, líricos e trágicos, os sete sábios e os filósofos pré-socráticos deram uma atenção especial às forças irracionais da alma. Depois essas forças encontraram um lugar de realce na sistematização

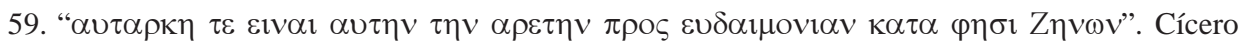
traduziu e comentou esta frase da seguinte maneira: "Isto foi magnificamente enunciado por Zenão como se fosse um oráculo (A Zenone hoc magnifice tamquam ex oraculo editur): Basta a virtude para se viver feliz (Virtus ad beate vivendum seipsa contenta est). Cf. Diógenes Laércio. VII, 127. Apud Nemesius Gonzalez Caminero. Op. cit., p. 81.

60. Diógenes Laércio. VI, I, 14. Apud Nemesius Gonzalez Caminero. Op. cit., p. 80.

61. Cf. Zeferino Rocha. "O desejo na Grécia Arcaica". Revista Latinoamericana de Psicopatologia Fundamental. São Paulo: Escuta. 2(4): 94-122; e "O desejo na Grécia Clássica”. Revista Latinoamericana de Psicopatologia Fundamental. Loc. cit. 3(1): 84-116. 


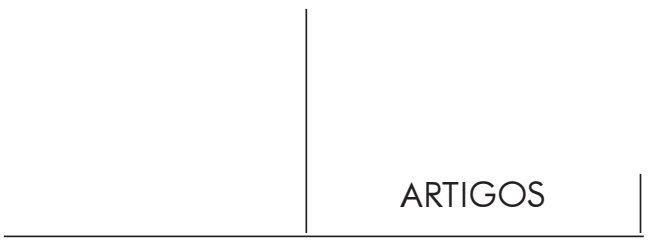

teórica que tanto Platão quanto Aristóteles fizeram sobre a doutrina da alma. O fato de eles reconhecerem a importância dessas forças irracionais, significava que nada poderia ser mais prejudicial ao equilíbrio da vida humana do que acorrentar as paixões ou querer extirpá-las. Bem orientadas, elas poderiam ter uma função de grande importância na vida do homem e da cidade.

Mas não pensavam assim os estóicos. Para eles, não havia lugar para as paixões em sua doutrina sobre a alma humana, porquanto esta era de natureza racional e a felicidade não podia ser alcançada senão na medida em que o homem conformava sua vida à sua natureza racional. Se não existiam, portanto, tendências irracionais na alma, as paixões deviam ser articuladas com a razão, seja como conseqüência de um "juízo falso", seja como uma "perversão" da própria razão.

Esta maneira de conceber a paixão perde um pouco de sua estranheza, se não nos esquecermos de que, para o sábio estóico, a felicidade, obtida na e pela virtude, devia ser entendida como um estado e uma disposição de espírito (uma $\delta \imath \alpha \theta \eta \sigma ı \varsigma$ ) sem a mínima perturbação ou preocupação. Ora, este ideal de absoluta tranqüilidade, sem dúvida, seria comprometido, se a razão devesse sempre se confrontar com as forças irracionais, que dela não dependem.

Zenão tentou explicar a natureza das paixões, vendo nelas a conseqüência de um falso juízo. Quando o homem é atraído pela riqueza, explicava ele, mas possui uma razão que não é corrompida pelas crenças, ele logo compreende que a riqueza é um "bem indiferente", ou seja, um bem que não é nem bom nem mau em si mesmo, um bem, portanto, que pode ser útil, quando atende às necessidades da vida. Todavia, se ele tiver uma razão já corrompida pelas crenças, facilmente fará um falso juízo sobre a riqueza, julgando-a um bem em si mesma. Desse falso juízo surge o movimento irracional que supervaloriza a riqueza além da justa medida. É nesse movimento irracional de desmedida, por conseguinte, que consiste a paixão pela riqueza, que pode revestir as formas da ambição e da avareza. A paixão, desse modo,

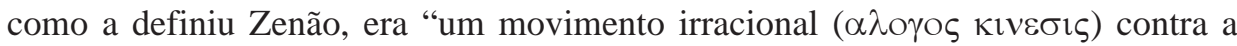
natureza da alma" ( $\pi \alpha \rho \alpha$ $\varphi v \sigma \imath v \psi \nu \chi \eta \varsigma),{ }^{62}$ ou como se exprimiu Cícero: "grandes

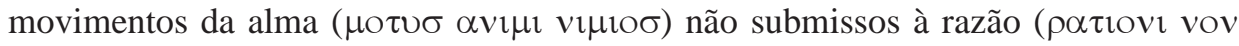
o $\beta \tau \varepsilon \mu \pi \varepsilon \rho \alpha \nu \tau \varepsilon \sigma){ }^{63}$

Crísipo escreveu quatro livros sobre as paixões, dos quais o quarto foi dedicado ao que ele próprio chamou um trabalho terapêutico. Partindo da premissa de que na alma só existia a parte racional, e nesta a faculdade cognitiva, ele via as paixões como "perversões" da razão, mediante as quais o homem era induzido a falsos juízos e a falsos conhecimentos. Assim sendo, o trabalho terapêutico não podia ser outro 


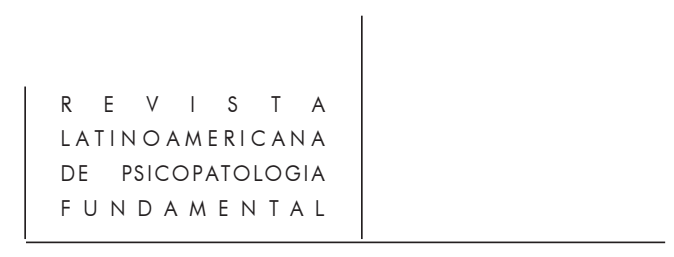

senão extirpar as paixões ou arrancar-lhes as raízes. Fiel a esta teoria, Sêneca também afirmava que "a paixão e a razão eram uma mudança da alma para melhor ou para pior" (affectus et ratio in melius peiusque mutatio animi est). ${ }^{64}$

De qualquer forma, seja para os partidários do dualismo zenoniano (racional irracional), seja para os sequazes do monismo de Crísipo que reduzia a paixão a uma perversão da razão, todos os estóicos admitiam que as paixões eram "contrárias à razão" ( $\pi \alpha \rho \alpha \varphi \varphi \sigma \imath v)$, "insubordinadas às diretrizes da razão" $(\alpha \pi \varepsilon \imath \theta \eta \tau \omega \lambda \circ \gamma \omega)$ e, conseqüentemente, "as paixões eram irracionais" ( $\pi \alpha \theta \eta \alpha \lambda \circ \gamma \alpha)$.

Uma vez que as paixões eram excessivas por natureza, impossível pensar um trabalho de controle da razão sobre elas. A este propósito, Nussbaum lembra uma metáfora empregada por Crísipo para demonstrar a impossibilidade de controle sobre as paixões. A metáfora compara o homem apaixonado àquele que corre e o nãoapaixonado àquele que caminha. Enquanto caminha, o homem sempre pode controlar o impulso de seus movimentos: ele regula a marcha como quer, pára e vai quando e aonde deseja. $\mathrm{O}$ apaixonado, pelo contrário, é apanhado num turbilhão que não pode controlar. Por isso, os estóicos diziam que a natureza nos fez sem paixões. Elas são adquiridas depois. E da mesma forma que as adquirimos, devemos delas nos libertar. Como? Extirpando-as de nossa vida.

Em resumo, o modo estóico de conceber as paixões levou-os a desconhecerem as forças irracionais que habitam em nós ou a reduzi-las a meros erros da razão. Seu ideal de felicidade, portanto, foi constituído ao preço de grandes mutilações à integridade da pessoa humana. Tem razão Giovanni Reale, quando termina seu estudo sobre as paixões na ética dos epicuristas e dos estóicos, afirmando que “... a dor e a morte assinalam o fracasso da ética da aponia e a maciça e irrecusável presença em nós do irracional assinala o fracasso da ética da apatia" ${ }^{65}$

\section{Uma nova maneira de ver o desejo}

Talvez fosse oportuno lembrar, rapidamente, a inovação e a reformulação que a doutrina do Pórtico Antigo sobre as paixões e os desejos sofreu no médio estoicismo e no estoicismo da era romana, embora não seja meu propósito abordá-las no presente trabalho. De modo diferente do que se passava no Jardim de Epicuro, em que a doutrina do mestre tinha a força dos dogmas, a doutrina de Zenão, fundador do Pórtico Antigo, foi submetida a revisões e críticas pelos seus sucessores, o que the assegurou um notável desenvolvimento e expressivas inovações. No que se refere à doutrina das paixões e do desejo, temos uma confirmação dessas inovações no médio 


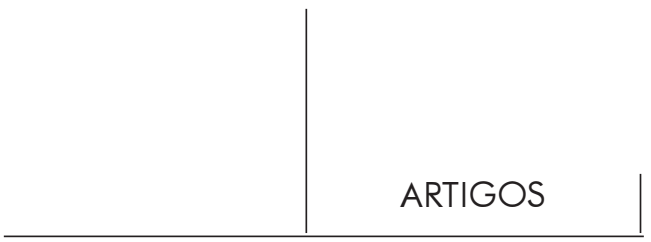

estoicismo de Panécio e Possidônio, que, nas últimas três décadas do século II a.C., revitalizaram o estoicismo.

Panécio admitia, na alma humana, duas forças opostas: o racional e o irracional. Assim fazendo, ele deu um lugar de destaque ao desejo, que era figurado como um "ar ígneo", no qual se encontrava a mola propulsora do agir humano. Assim, era possível falar-se de conflito, o que não acontecia na maneira como o Pórtico Antigo concebia as paixões. O desejo passava a ter um lugar e podia confrontar-se com a razão. Para traduzir esta inovação, creio que seja oportuno lembrar o diálogo que

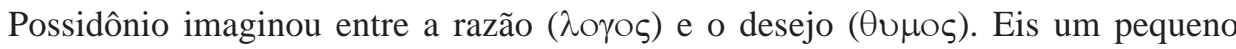
fragmento do diálogo:

Razão: O que é que queres, ó desejo, dize-me.

Desejo: Que tu, ó razão, faças tudo aquilo que eu quero.

Razão: Grandes coisas tu dizes, todavia, dize-o de outro modo.

Desejo: Que tudo o que desejo, seja posto em execução. ${ }^{66}$

Pode-se deduzir desse diálogo que, para o médio estoicismo, o desejo, seja sob a forma do amor ardente $(\theta \cup \mu \circ \varsigma)$, seja sob a forma do apetite irracional $(\varepsilon \pi \imath \theta \cup \mu \imath \alpha)$, passou a ter vez e voz e a fazer valer sua vontade diante da razão onipotente que reinava soberana no Pórtico Antigo.

Todavia, essa inovação na doutrina do desejo foi acompanhada por uma reformulação mais profunda do próprio ideal de felicidade, que o Pórtico Antigo, como vimos, reduzia essencialmente à insensibilidade $(\alpha \pi \alpha \theta \imath \alpha)$. Talvez porque, no médio estoicismo, já se vislumbravam alguns ideais cívicos que os homens do Pórtico Antigo não conseguiram ver, os novos mestres do estoicismo tenham se dado o direito de questionar o ideal ético que seus predecessores ofereceram aos homens de seu tempo. Quando começavam a despontar, nos horizontes políticos, os raios de uma nova civilização, foi possível aos filósofos cantar uma ode à "alegria de viver", levando o triste ideal de insensibilidade $(\alpha \pi \alpha \theta \varepsilon 1 \alpha)$ a ceder, aos poucos, seu lugar a um ideal de alegria $(\varepsilon \cup \theta v \mu \imath \alpha)$.

\section{Na Era Imperial}

Sem perder as características de uma filosofia concebida essencialmente como "uma arte de viver" (ars vivendi), o estoicismo que conquistou Roma revestiu-se de propriedades que o Pórtico Antigo desconheceu. Assim, por exemplo, o primado da consciência no campo da ética. A consciência passou a ser vista como o "verdadeiro juiz" da vida moral. Dela ninguém conseguia esconder-se. Ela era o 


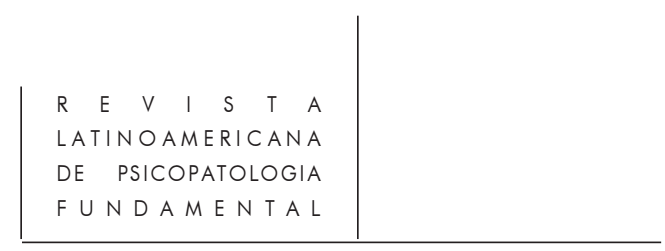

flagelo de nossos erros ${ }^{67}$ Além disso, Sêneca, Epicteto e Marco Aurélio trabalharam a questão ética numa atmosfera verdadeiramente religiosa e divulgaram máximas e preceitos que evocavam as máximas e os preceitos cristãos e evangélicos. Bastaria lembrar a maneira como Sêneca falava de Deus. "Não se sabe como, dizia ele, mas um deus habita em cada homem virtuoso". ${ }^{68}$ Quando se encontra diante das forças espantosas da natureza, ou da paz de sua imensidão silenciosa, "a alma do homem é tomada pelo sentido do religioso mistério". ${ }^{69}$

Na filosofia de Sêneca, um lugar de realce foi dado à vontade, que quase passou despercebida no Pórtico Antigo, e esta ênfase permitiu que o instinto de conservação, que os antigos tanto valorizaram, fosse substituído pela vontade de viver.

Já Epicteto, o filósofo-escravo, embora reafirmando a tese de que era fundamental, para adquirir a virtude, renunciar aos desejos e suprimir as paixões, chamava a atenção para "as coisas que nos são próprias" (os nossos próprios atos) e as distinguia das "coisas que não estão em nosso poder". Quem escolhe as coisas que estão em seu poder, descobre o segredo da verdadeira liberdade e, vivendo a vida que quer, encontra o segredo da felicidade. Ao passo que desejar o que não está em nosso poder é condenar-se às desilusões e contrariedades. Daí uma máxima de Epicteto de grande sabedoria: "Não busques que os acontecimentos aconteçam como queres, busca, ao invés, querer que eles aconteçam como acontecem". ${ }^{70}$

Marco Aurélio, o filósofo-imperador inova bastante a visão do homem, típica do Pórtico Antigo, quando distingue no homem: o corpo $(\sigma \omega \mu \alpha)$, a alma ( $\psi \vee \chi \eta)$ e o intelecto ou a mente (vous), que é superior à própria alma. Do corpo, surgem as sensações; da alma, os instintos, os desejos e as paixões; e do intelecto, as idéias. Quando não se ressalta o valor do intelecto, negligencia-se o que há de mais importante no homem. É verdade, como muito bem observa Giovanni Reale, que faltou a Marco Aurélio uma fundamentação adequada para definir a estrutura suprasensível do intelecto. ${ }^{71}$

Mas, como quer que seja, o "intelecto" (vous), quando não é corrompido pelas falsas opiniões, oferece ao homem um refúgio, no qual ele pode se recolher na solidão de sua interioridade. "Recolhe-te, pois, amiúde, aconselha Marco Aurélio, nessa solidão e renova-te". ${ }^{72} \mathrm{O}$ intelecto, centelha divina emanada do deus-fogo, une os

67. Sêneca. Epist. 79, 12-16. Apud Giovanni Reale. História da filosofia antiga. Escolas da era imperial. Loc. cit., p. 66.

68. Sêneca. Ep. 41, 1-5. Apud Giovanni Reale. Ibid., p. 72.

69. Id., ibid.

70. Epicteto, Manual, 8. Apud Giovanni Reale. História da filosofia antiga. Escolas da era imperial. Loc. cit., p. 96.

71. Giovanni Reale. Ibid., p. 117.

72. Marco Aurélio, Solilóquios, IV, 3. Apud. Giovanni Reale. Ibid., p. 121. 


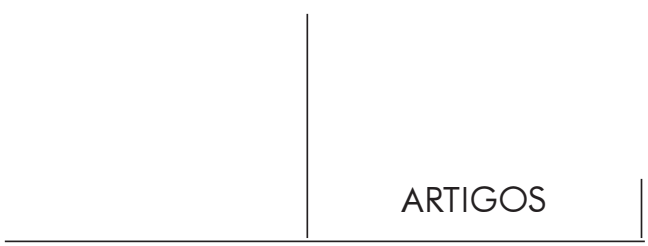

homens mais do que numa comunhão harmoniosa, como queria o Pórtico Antigo, mas numa verdadeira "comunhão de amor".

Para florescerem, porém, essas idéias exigiam uma outra fundamentação ontológica, diferente do "materialismo" que sempre marcou a filosofia estóica. Daí porque, depois de Marco Aurélio, o estoicismo foi declinando e, no século III d.C., desapareceu do cenário filosófico. ${ }^{73}$

\section{Resumos}

El presente trabajo es la tercera y la última parte de una encuesta sobre "El deseo en la Grecia antigua”. En la primera parte, reunimos las manifestaciones del deseo en los poemas épicos, líricos y tragicos, así como en las máximas de los siete sabios y en la doctrina de los filósofos pre-socraticos de la Grecia arcaica. En la segunda, presentamos el esencial de la sistematización teorica que, en la Grecia clasica, Socrates, Platon y Aristoteles dieron a esas primeras manifestaciones del deseo. En esta ultima parte, despues de recordar la origen y las caracteristicas de la cultura helenistica, veremos lo que los epicuristas y los estoicos, en el contexto de sus respectivas filosofias, dijeron sobre el deseo en el jardín de Epicuro y enel Portico antiguo de Zenon y Crispo.

Palavras llave: Cultura helenistica, arte de vivir, placer, virtud, felicidad

Le présent travail est la troisième partie d'une recherche sur "Le désir dans la Grèce Ancienne”. La première partie a réuni les manifestations du désir dans les poèmes épiques, lyriques et tragiques, dans les Maximes des Sept Sages et dans la doctrine des premiers philosophes de la Grèce Archaïque. La deuxième partie a présenté l'essentiel de la systématisation théorique que Socrate, Platon et Aristotle ont donné a ces premières manifestations du désir. Dans cette dernière partie, après avoir rappelée l'origine et les caractéristiques de la culture hellénistique, nous avons travaillé ce que les épicuriciens et les stoiciens, dans le contexte de leurs respectives doctrines ont dit sur le désir dans le Jardin d'Épicure et dans le Portique Ancien de Zenon et Crisippe.

Mots clé: Culture hellénistique, art de vivre, plaisir, vertu, félicité

This word is the third and last part of a research on "The desire in Ancient Greece". In the first part we gathered the manifestation of the desire in the epic, lyric and tragic poems, as well as in the seven wises' maxims and in the Archaic Greece presocratic philosophers' doctrine. In the second one, we presented the core of the theoretical sistematizations that, in the Classic Greece, Socrate, Plato and Aristotle

73. Sobre as causas que levaram à dissolução da filosofia do pórtico na era romana, ver Giovanni Reale. Ibid., pp. 125-128. 


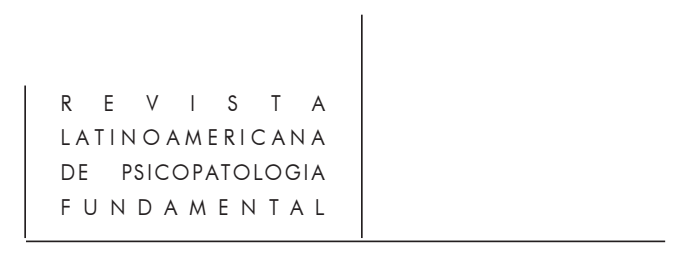

provided to those first manifestations of the desire. In the last part, after reminding the origin and characteristics of the Helenistic culture, we shall see what the epicureans and the stoics said, in the context of their respective philosophies, about the desire at the Epicure's Garden and at the Zeno and Chrisipo's Ancient Portico.

Key words: Helenistic culture, art of living, pleasure, virtue, happiness 